\title{
А. А. Кудь
}

\section{Методика диагностики токена блокчейна на соответствие цифровому активу}

Методическое пособие

\author{
Харьков \\ "ХОГОКЗ" \\ 2019
}


УДК 001.891.5:330.47:33.053.22(072)

DOI 10.26697/9786177089055.2019

K 88

Рекомендовано к печати научно-методическим советом

Научно-исследовательского института ХОГОКЗ

(протокол № 01 от 30 марта 2019 года)

\section{Рецензенты:}

Кучерявенко Н. П. - доктор юридических наук, кандидат экономических наук, профессор, заведующий кафедрой финансового права Национального юридического университета имени Ярослава Мудрого, первый вице-президент Национальной академии правовых наук Украины.

Марченко О. С. - доктор экономических наук, профессор, профессор кафедры экономической теории Национального юридического университета имени Ярослава Мудрого.

Макаричев А. В. - доктор физико-математических наук, доцент, профессор кафедры транспортных технологий и технического сервиса учебно-научного механического института НУВПХ, ведущий научный сотрудник кафедры транспортных систем и логистики ХНАДУ.

Кудь А. А. Методика диагностики токена блокчейна на соответствие цифровому активу: методическое пособие / к 88 НИИ ХОГОКЗ. Харьков: ХОГОКЗ, 2019.56 с. doi: $10.26697 / 9786177089055.2019$

\section{ISBN 978-617-7089-05-5}

В издании приведены критерии и показатели характеристик токена блокчейна, представлена методика диагностики и методика по математической обработке данных. Методическое пособие разработано с целью установления соответствия токена блокчейна цифровому активу на основании результатов его исследования, в том числе правовой характеристики токена блокчейна, и предназначено специалистам в области информационной и цифровой экономики, юристам, финансовым организациям, представителям бизнессообществ.

$$
\text { УДК 001.891.5:330.47:33.053.22(072) }
$$

(C) Кудь А. А., 2019

ISBN 978-617-7089-05-5 은, ХОГОКЗ, оформление, 2019 


\section{СОДЕРЖАНИЕ}

ПРЕДИСЛОВИЕ

4

РАЗДЕЛ 1. ТЕОРЕТИЧЕСКИЕ ОСНОВЫ ТОКЕНА БЛОКЧЕЙНА КАК ЦИФРОВОГО АКТИВА

1.1. Развитие технологии блокчейн: криптовалюты, токены, цифровые активы

6

1.2. Комплекс дефиниций основных понятий, отождествляемых с токеном блокчейна

1.3. Компоненты в контексте определения понятия «цифровой актив»

1.4. Характеристики критериев и показателей токена блокчейна как цифрового актива

РАЗДЕЛ 2. ОРГАНИЗАЦИЯ И ПРОВЕДЕНИЕ ИССЛЕДОВАНИЯ ХАРАКТЕРИСТИК ТОКЕНА БЛОКЧЕЙНА

2.1. Исследование характеристик токена блокчейна

2.2. Анализ результатов исследования

2.3. Интерпретация результатов исследования

РАЗДЕЛ 3. МАТЕМАТИЧЕСКАЯ

ФОРМАЛИЗАЦИЯ МЕТОДИКИ ДИАГНОСТИКИ ХАРАКТЕРИСТИК ТОКЕНА БЛОКЧЕЙНА НА СООТВЕТСТВИЕ ЦИФРОВОМУ АКТИВУ

3.1. Тройственная классификация по результатам

диагностики токена блокчейна на соответствие

цифровому активу

3.2. Достоверность методики диагностики токена

блокчейна в зависимости от величины набранных баллов

ВЫВОДЫ 


\section{ПРЕДИСЛОВИЕ}

Современная мировая финансовая система претерпевает значительные изменения, во многом обусловленные становлением новой ее отрасли - информационной экономики на базе технологии блокчейн.

Реализация и развитие технологии распределенного реестра типа бухгалтерских книг, каждая из которых имеет одинаковые записи данных и совместно поддерживается и контролируется распределенной сетью компьютерных серверов, способствовали возникновению новой технологии - блокчейн.

На сегодняшний день технология блокчейн воспринимается обществом как новый механизм распространения цифровой информации. В частности, она привлекает профессионалов в области финансов, которые сначала заинтересовались блокчейном как технологией бухгалтерской книги, но затем, осознав ее колоссальный потенциал, на этой основе начали создавать цифровые валюты и искать другие варианты ее применения. Активное внедрение технологии блокчейн и выявленные преимущества ее использования свидетельствуют о закономерности естественных глобальных преобразований, которые затрагивают политическую, правовую, социально-экономическую и другие сферы жизни общества.

Таким образом, становится очевидным, что чем раньше учреждения и организации, как государственные, так и негосударственные, смогут использовать эту технологию для оптимизации своей деятельности, тем более инновационными и конкурентоспособными станут их продукты и сервисы. Использование токенов блокчейна для регистрации и обмена правами собственности на активы и в принципе любых видов прав приведет к кардинальной трансформации в различных отраслях, сравнимой по своей значимости с заменой компьютерами печатных машинок, не говоря уже об оптимизации процессов, связанных с учетом и обменом информацией посредством цифровых активов. 
Основными задачами этого пособия являются: отобразить характеристики токена блокчейна, которые лежат в основе понятия «цифровой актив»; определить критерии и показатели характеристик токена блокчейна; представить методику диагностики токена блокчейна на соответствие цифровому активу и методику по математической обработке данных для такой оценки.

Таким образом, данное методическое пособие позволит установить соответствие любого токена блокчейна цифровому активу. 


\section{РАЗДЕЛ 1 \\ ТЕОРЕТИЧЕСКИЕ ОСНОВЫ \\ ТОКЕНА БЛОКЧЕЙНА КАК ЦИФРОВОГО АКТИВА}

\section{1. Развитие технологии блокчейн: криптовалюты, токены, цифровые активы}

Развитие цифровой экономики в целом и цифровых технологий в частности обусловили появление нового понятия «цифровой актив»- и поэтапное внедрение связанных с ним процессов.

Использование понятия цифрового актива в современном понимании в первую очередь вызвано появлением технологии блокчейн и криптовалют.

Блокчейн - это определенный тип или подмножество так называемой технологии распределенного реестра (DLT Distributed Ledger Technology). Эта технология представляет собой механизм, который использует метод шифрования, известный как криптография, и набор специфических математических алгоритмов для создания и проверки постоянно растущей структуры данных, в которую можно добавлять данные и из которой нельзя удалить существующие данные - форма цепочки «транзакционных блоков», функционирующая как распределенный реестр.

Простыми словами, блокчейн можно рассматривать как распределенную базу данных. Добавление к этой базе данных инициируется одним из узлов сети (ноды), который создает новый блок данных, который может содержать различные виды информации. Этот новый блок передается каждой стороне в сети (с использованием криптографии). Другие ноды совместно определяют срок действия блока согласно заранее определенному методу алгоритмической проверки, который обычно называют «механизмом консенсуса». После проверки новый блок включается в цепочку из блоков публичного распределенного реестра (блокчейна), что, по сути, приводит к обновлению реестра транзакций, и распределяется по сети. 
Одним из ключевых преимуществ технологии блокчейн является то, что она позволяет упростить выполнение широкого спектра операций, которые обычно требуют посредничества третьей стороны, то есть полностью исключить посредников из процесса взаимодействия двух сторон.

Принимая во внимание, что технология блокчейн часто связана с цифровыми или виртуальными валютными схемами, платежами и финансовыми услугами, необходимо отметить гораздо более широкую сферу ее использования. Практически блокчейн уже применяется в различных секторах (например, торговля и коммерция, здравоохранение, сферы государственного управления, логистика, банковский сектор и т. п.).

Следует отметить, что криптовалюта является первым общеизвестным применением технологии блокчейн, которая сформировала основы крипторынка и обусловила все разнообразие криптовалют. При этом на сегодняшний день можно отметить тот факт, что блокчейн явно перерос контекст криптовалют и как технология способен применяться во многих сферах жизни общества.

С момента появления первой виртуальной валюты в 2009 году тема криптовалют и блокчейна изучалась различными международными организациями и государственными учреждениями, каждое из которых рассматривало ее по-разному. Основополагающими документами для выяснения сущности исследуемых понятий являются официальные публикации международных органов регулирования и контроля в этой сфере.

Европейский центральный банк (ЕСВ - European Central Bank) классифицировал криптовалюту как подгруппу виртуальных валют. В докладе о схемах виртуальных валют в 2012 году ЕСВ определил такие валюты как форму нерегулируемых цифровых денег, которые, как правило, выпускаются и контролируются их разработчиками, используются и принимаются среди членов конкретного виртуального сообщества. 
ЕСВ также уточнил, что можно выделить три типа виртуальных валют в зависимости от взаимодействия с традиционными валютами и реальной экономикой:

1) виртуальные валюты, которые можно использовать только в закрытой виртуальной системе, как правило, в онлайниграх;

2) виртуальные валюты, которые в одностороннем порядке связаны с реальной экономикой: существует коэффициент конверсии на покупку валюты (с традиционными деньгами), а приобретенная валюта может быть впоследствии использована для покупки виртуальных или реальных товаров и услуг;

3) виртуальные валюты, которые являются двусторонне связанными с реальной экономикой: существуют курсы конверсии как для покупки виртуальной валюты, так и для продажи такой валюты; купленная валюта может быть использована для покупки как виртуальных, так и реальных товаров и услуг [1, с. 13-19].

В более позднем отчете в 2015 году ЕСВ выдвинул еще одно и в значительной степени обновленное определение виртуальных валют как цифровых выражений ценности, которые не выданы центральным банком, кредитным учреждением или электронным денежным учреждением и при определенных обстоятельствах могут быть использованы в качестве альтернативы деньгам [2, с. 4].

Как и Европейский центральный банк, Международный валютный фонд (IMF - International Monetary Fund) классифицировал криптовалюту как подмножество виртуальных валют, которые он определяет как цифровые выражения ценности, выданные частными разработчиками и деноминированные в собственной единице счета [3, с. 7].

Согласно данным IMF, концепция виртуальных валют охватывает более широкий спектр валют, начиная от простых производных финансовых инструментов (IOUs) виртуальных валют, которые обеспечиваются различными активами, например, золотом или реально существующей собственностью, до электронных денег и криптовалют. 
Комитет по вопросам платежной и рыночной инфраструктуры (СРMI - Committee on Payments and Market Infrastructures), орган Банка международных расчетов (BIS - Bank for International Settlements), определил криптовалюту как цифровую валюту или схемы цифровой валюты.

Эти схемы имеют следующие ключевые особенности:

- являются активами, ценность которых определяется спросом и предложением, похожими по определению на такие товары, как золото, но с нулевой внутренней ценностью;

- используют распределенный реестр, что позволяет осуществлять дистанционный обмен электронными ценностями по принципу peer-to-peer (равный к равному) при отсутствии доверия между сторонами и без необходимости в посредниках;

- не находятся под управлением одного конкретного лица или учреждения [4, с. 4-7].

Европейская служба банковского надзора (EBA - European Banking Authority) предложила ссылаться на криптовалюту как на виртуальную валюту, определяемую как цифровые выражения ценности, которые не выдаются центральным банком или государственными органами, необязательно прикреплены к фиатной валюте, но используются физическими или юридическими лицами как средство обмена и могут передаваться, храниться или торговаться в электронном виде [5, с. 11].

Европейская организация по ценным бумагам и рынкам (ESMA - European Securities and Markets Authority) также ссылается на криптовалюты как на виртуальные валюты в общеевропейской директиве, изданной в сотрудничестве с Европейской организацией страхования и пенсионного обеспечения (EIOPA - European Insurance and Occupational Pensions Authority) и EBA. Полностью в соответствии с определением ЕВА, виртуальные валюты определяются как цифровые выражения ценности, которые не выпускаются и не гарантируются центральным банком или государственными органами и не имеют правового статуса валюты или денег [6, с. 1]. 
Всемирный банк (World Bank) квалифицировал криптовалюту как подмножество цифровых валют, которые он определяет как цифровые выражения ценности, номинированные в собственную единицу счета, отличные от электронных денег, которые являются цифровым механизмом платежей, представленные и выраженные в фиатных деньгах. Всемирный банк также определил криптовалюты как цифровые валюты, которые опираются на криптографические методы для достижения консенсуса [7].

Группа разработки финансовых мер борьбы с отмыванием денег (FATF - Financial Action Task Force) как межправительственная организация, которая занимается выработкой мировых стандартов в сфере противодействия отмыванию преступных доходов и финансированию терроризма, подошла к криптовалюте как к подмножеству виртуальных валют, определяемых как цифровые выражения ценности, которые могут быть обработаны в цифровом формате и функционировать как средство обмена; и/или расчетная единица; и/или хранилище ценности, но не иметь статуса законного платежного средства в любой юрисдикции. При этом виртуальные валюты можно разделить на два основных типа:

- конвертируемые виртуальные валюты, имеющие эквивалентную стоимость в реальной валюте, которые могут быть обменяны обратно на фиатные валюты; эти виртуальные валюты могут иметь централизованный или децентрализованный характер (то есть они могут как иметь центральный административный орган, контролирующий систему, так и не иметь центрального контроля вообще);

- неконвертируемые виртуальные валюты, которые являются специфическими для определенного виртуального домена или мира, и в соответствии с правилами, регулирующими его использование, не могут обмениваться на фиатную валюту [8, с. 4-5].

Свойства и функции некоторых токенов блокчейна соотносятся со свойствами и функциями традиционных финансовых инструментов, таких как акции или облигации, и обычно их называют security-токенами или investment-токенами. 
Другие токены блокчейна предоставляют своим владельцам доступ к определенным продуктам или сервисам, и их обычно называют utility-токенами. Их можно использовать для приобретения определенных товаров или услуг, но они не являются средством обмена общего назначения, потому что, как правило, могут использоваться только на самой блокчейнплатформе токенов.

Особенность правового регулирования этих отношений связана с согласованием регулирования обращения виртуальных валют на национальном и международном уровнях. В этих условиях регулирование обращения виртуальных валют связывается с определенной двойственностью согласования. Вопервых, речь идет о сочетании регулирования этих отношений как в рамках национального законодательства, так и на международном уровне. Во-вторых, общественные отношения, связанные с оборотом виртуальных валют, имеют комплексный характер, предусматривающий как регулирование их средствами частного и публичного права, так и выделение отдельных аспектов этих отношений в качестве предмета гражданского, хозяйственного и финансового права.

Определенную сложность добавляет и многоуровневость соотношения нормативных предписаний в пределах одного государства. В 2017 году Комиссией по унификации права (Uniform Law Commission) был разработан Uniform Regulation of Virtual-Currency Business Act - унифицированный акт по регулированию деятельности, связанной с виртуальной валютой. Хозяйственная деятельность, связанная с виртуальными валютами, указанная в данном акте, является идентичной услугам, которые уже являются предметом лицензирования и пруденциального регулирования в статусе «поставщики денег» или «денежных переводов» во многих штатах. В 2018 году данный акт был дополнен Uniform Supplemental Commercial Law for the Uniform Regulation of Virtual-Currency Businesses Act унифицированным актом о коммерческом законе для единого регулирования виртуальной валюты.

Особенностью таких унифицированных актов является то, что они автоматически не включаются ни в федеральное 
законодательство США, ни в законодательство субъектов федерации. Данные акты являются ориентирами для нормотворческих органов в процессе разработки законодательства в соответствующей сфере.

Значительное количество негативных аспектов по применению виртуальных валют связано с отсутствием правовой оценки этого явления, неопределенностью их правовой природы, что значительно усложняет разработку соответствующей нормативно-правовой базы.

На сегодняшний день ни на международном, ни на национальном уровнях единого устоявшегося подхода к содержательному наполнению понятия «виртуальная валюта» не закреплено. В различных обстоятельствах ее определяют как деньги, электронные деньги, валюту, финансовый инструмент, средство платежа, средство обмена, тип цифровых денег, цифровое представление стоимости, тип актива, нематериальный актив и т.Д. Отсутствие четкости в определении виртуальной валюты дополняется и множественностью тождественных понятий. Наряду с виртуальной валютой, применяются такие понятия, как «криптовалюта», «криптоактив», «цифровой финансовый актив».

Главный вывод, который можно сделать, исходя из вышеизложенного, заключается в том, что не существует общепринятого определения понятия криптовалюта, доступного в нормативном пространстве. Большинство государственных учреждений и международных организаций воздержались от определения термина вообще. Среди упомянутых выше институций только Всемирный банк и FATF предложили четкое определение. Однако понятно, что большинство упомянутых учреждений и организаций подходят к криптовалюте как подмножеству или форме виртуальных или цифровых валют. 


\section{2. Комплекс дефиниций основных понятий, отождествляемых с токеном блокчейна}

Теоретическую ценность и практическую значимость для разработки понятийно-категориального аппарата имели работы ученых экономической и финансово-правовой сфер, а также практиков сферы информационных технологий, которые применяют различные дефиниции терминов «цифровая валюта», «виртуальная валюта», «криптовалюта», «цифровой актив», «виртуальный актив», «криптоактив», «цифровые деньги», «виртуальные деньги», «электронные деньги». Эти понятия не являются тождественными и имеют свои сущностные особенности.

В таблице 1 представлен комплекс дефиниций основных понятий, отождествляемых с токеном блокчейна.

Таблица 1

\section{Комплекс дефиниций}

\begin{tabular}{|c|c|}
\hline Понятие & Дефиниция \\
\hline Криптовалюта & 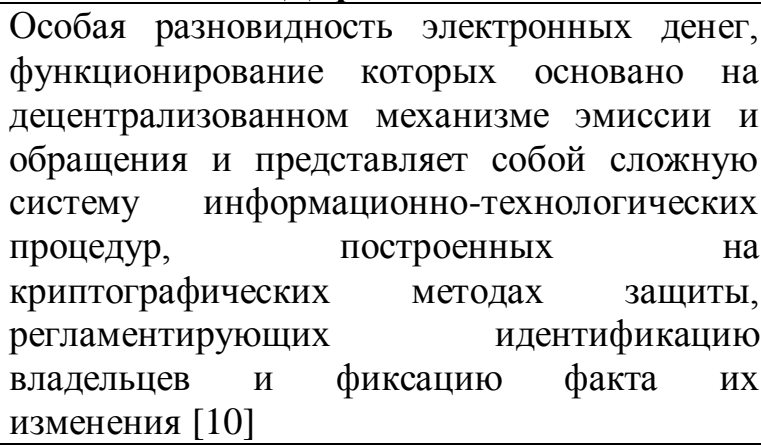 \\
\hline Криптовалюта & $\begin{array}{l}\text { Цифровая валюта, в которой } \\
\text { шетоды } \\
\text { регулирования выработки единиц валюты и } \\
\text { проверки перевода средств, действуя } \\
\text { независимо от центрального банка [1] }\end{array}$ \\
\hline Криптовалюта & $\begin{array}{l}\text { Цифровая валюта, построенная на } \\
\text { криптографических протоколах, которые } \\
\text { делают транзакции безопасными и трудными } \\
\text { для подделки, она не контролируется любой }\end{array}$ \\
\hline
\end{tabular}




\begin{tabular}{|c|c|}
\hline Понятие & Дефиниция \\
\hline & $\begin{array}{l}\text { центральной властью; облегчает проведение } \\
\text { любых транзакций, поскольку переводы } \\
\text { упрощаются благодаря использованию } \\
\text { открытых и закрытых ключей в целях } \\
\text { безопасности и конфиденциальности [12] }\end{array}$ \\
\hline Криптовалюта & $\begin{array}{l}\text { Цифровая или виртуальная валюта, которая } \\
\text { использует криптографию для обеспечения } \\
\text { безопасности [13] }\end{array}$ \\
\hline Криптовалюта & 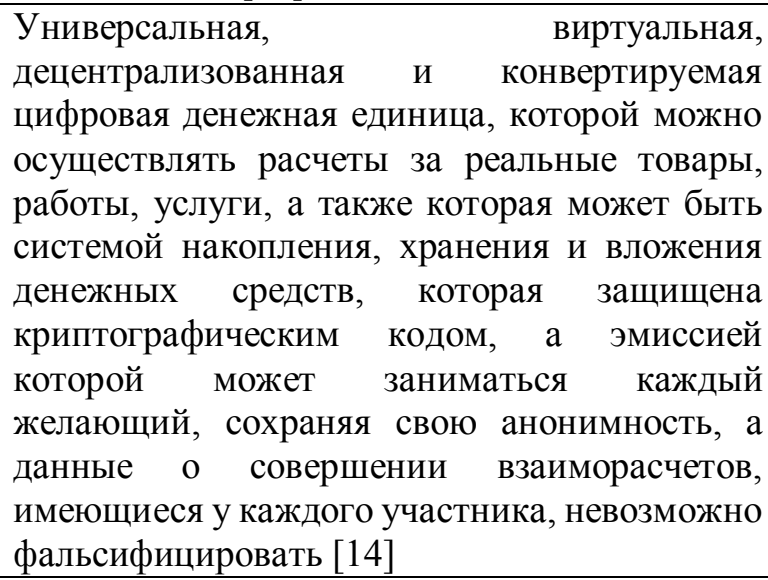 \\
\hline Криптовалюта & $\begin{array}{l}\text { Цифровой актив, который функционирует как } \\
\text { средство обмена, очень похож на наличные в } \\
\text { цифровой форме [15] }\end{array}$ \\
\hline Криптовалюта & 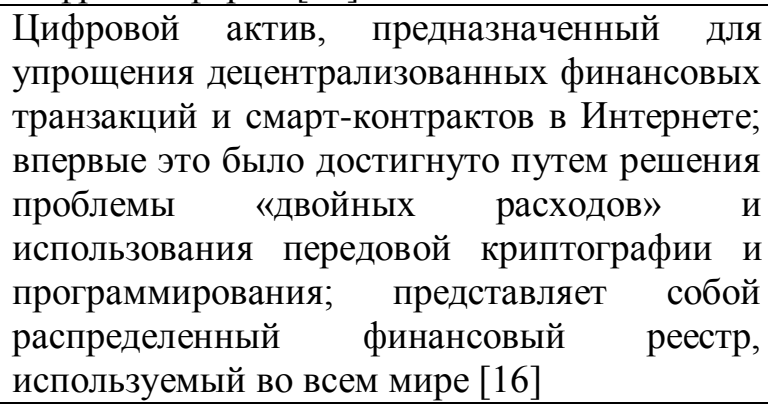 \\
\hline Криптовалюта & $\begin{array}{lcc}\text { Информационный } & \text { актив, } \\
\text { результатом } & \text { прляюизводственной, } \\
\text { коммерческой } & \text { и } & \text { финансовой } \\
\end{array}$ \\
\hline
\end{tabular}




\begin{tabular}{|c|c|}
\hline Понятие & Дефиниция \\
\hline & $\begin{array}{l}\text { предприятия и находящийся на его балансе, а } \\
\text { также обеспечивающий достижение } \\
\text { предполагаемых им целей; информационный } \\
\text { актив - это коммуникационный инструмент } \\
\text { финансово-экономических } \\
\text { функционирование которого основано на } \\
\text { современных информационных технологиях, } \\
\text { телекоммуникационных системах, } \\
\text { криптографии и т. д., контролируемый } \\
\text { предприятием в результате прошлых событий } \\
\text { и использование которого, как ожидается, } \\
\text { приведет к получению экономических выгод } \\
\text { в будущем [17] }\end{array}$ \\
\hline Криптовалюта & $\begin{array}{l}\text { Цифровой носитель, } \\
\text { оботорым }\end{array}$ \\
\hline $\begin{array}{l}\text { Виртуальная } \\
\text { валюта }\end{array}$ & 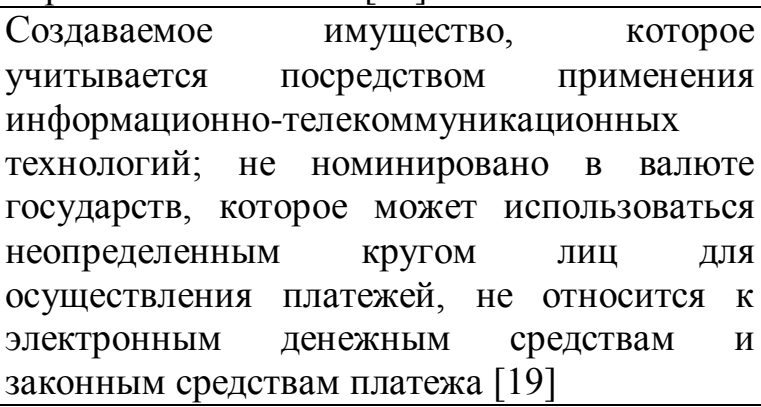 \\
\hline Криптоактив & 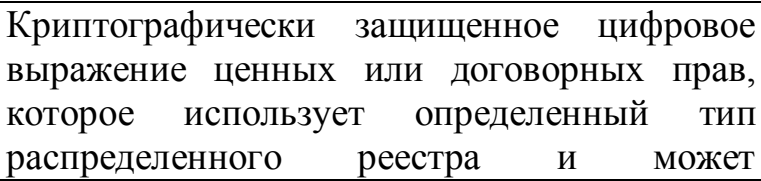 \\
\hline
\end{tabular}




\begin{tabular}{|c|c|}
\hline Понятие & Дефиниция \\
\hline & $\begin{array}{l}\text { передаваться, храниться или продаваться в } \\
\text { электронном виде [20] }\end{array}$ \\
\hline Криптоактив & $\begin{array}{l}\text { Цифровое выражение ценности, что стало } \\
\text { возможным благодаря достижениям в области } \\
\text { криптографии и технологии распределенного } \\
\text { реестра; криптоактивы выражены в своих } \\
\text { собственных единицах учета и могут быть } \\
\text { переданы в одноранговой сети без } \\
\text { посредников [21] }\end{array}$ \\
\hline $\begin{array}{l}\text { Виртуальный } \\
\text { актив }\end{array}$ & $\begin{array}{l}\text { Выражение валюты в определенной среде или } \\
\text { ситуации; в этом контексте валюту можно } \\
\text { определить либо как средство обмена, либо } \\
\text { как собственность, которая имеет ценность в } \\
\text { определенной среде. Денежные виртуальные } \\
\text { активы часто называют виртуальной } \\
\text { валютой [22] }\end{array}$ \\
\hline $\begin{array}{l}\text { Виртуальный } \\
\text { актив }\end{array}$ & 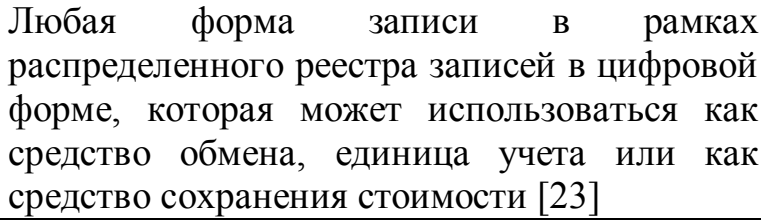 \\
\hline $\begin{array}{l}\text { Цифровой } \\
\text { актив }\end{array}$ & $\begin{array}{l}\text { Любой текст или носитель информации, } \\
\text { отформатированный в двоичный источник и } \\
\text { включающий право на его использование; } \\
\text { цифровые файлы, которые не включают это } \\
\text { право, не считаются цифровыми } \\
\text { активами [11] }\end{array}$ \\
\hline $\begin{array}{l}\text { Цифровой } \\
\text { актив }\end{array}$ & $\begin{array}{l}\text { Контент, который хранится в цифровом виде } \\
\text { (изображения, фотографии, видео, файлы, } \\
\text { содержащие текст, электронные таблицы или } \\
\text { слайды), это любой контент в любом формате, } \\
\text { который хранится в цифровом виде и } \\
\text { представляет ценность для компании } \\
\text { (пользователя или потребителя) [24] }\end{array}$ \\
\hline
\end{tabular}




\begin{tabular}{|c|c|}
\hline Понятие & Дефиниция \\
\hline $\begin{array}{l}\text { Цифровой } \\
\text { актив }\end{array}$ & $\begin{array}{llr}\text { Совокупность } & \text { двоичных данных, которая } \\
\text { является } & \text { автономной, } \\
\text { идентифицированной и имеет ценность [25] }\end{array}$ \\
\hline $\begin{array}{l}\text { Цифровой } \\
\text { актив }\end{array}$ & $\begin{array}{l}\text { Совокупность метаданных, которые ценятся и } \\
\text { усложняются, чем больше вы их связываете, } \\
\text { это также означает, что они могут } \\
\text { использоваться для неограниченного } \\
\text { диапазона применений; } \text { большинство } \\
\text { цифровых активов имеют установленную } \\
\text { денежную ценность, поскольку } \\
\text { представляют собой } \\
\text { принадлежащих оцифровку элементов, } \\
\text { организации; ценность активов обычно } \\
\text { увеличивается в с соответствии с } \\
\text { использованием [26] }\end{array}$ \\
\hline $\begin{array}{l}\text { Электронные } \\
\text { деньги }\end{array}$ & 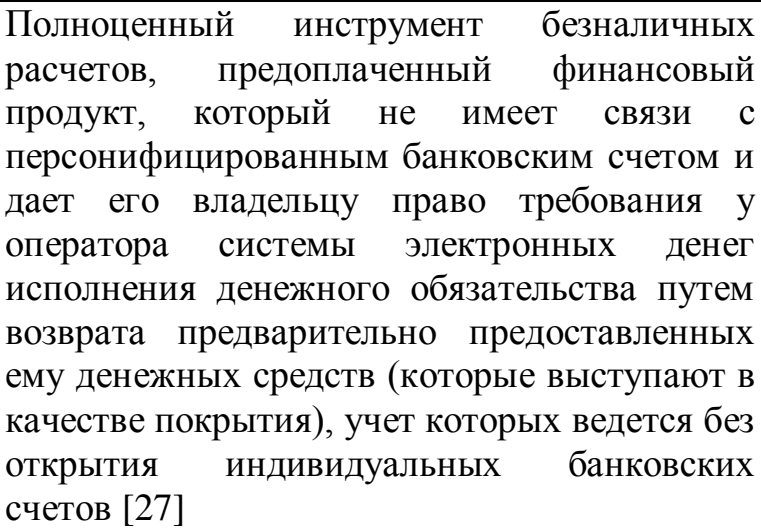 \\
\hline $\begin{array}{l}\text { Электронные } \\
\text { деньги }\end{array}$ & 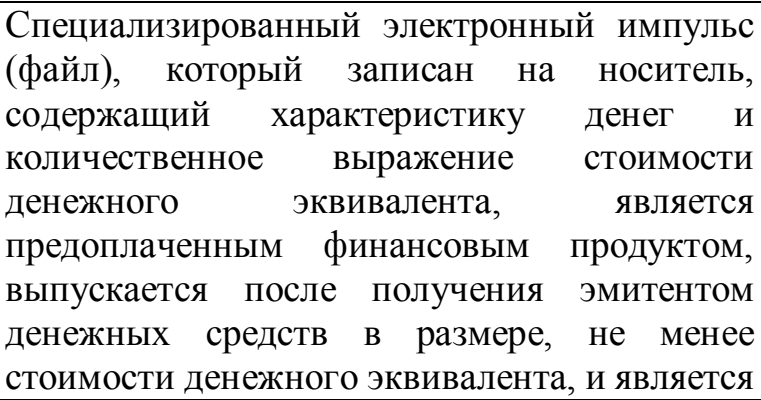 \\
\hline
\end{tabular}




\begin{tabular}{|c|c|}
\hline Понятие & Дефиниция \\
\hline & \begin{tabular}{llr} 
обязательствами & \multicolumn{2}{r}{ эмитента, которому } \\
корреспондируется право требования к \\
владельцу таких электронных денег по их \\
погашению [28]
\end{tabular} \\
\hline $\begin{array}{l}\text { Виртуальные } \\
\text { деньги }\end{array}$ & 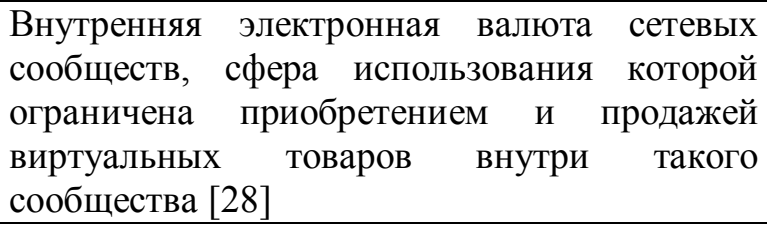 \\
\hline
\end{tabular}

Таким образом, современное развитие новых форм выражения цифровых технологий характеризуется настолько высокой динамикой, что формирование соответствующего теоретического основания и конкретного понятийнокатегориального аппарата значительно отстает, поэтому в научных публикациях и происходит отождествление вышеупомянутых категорий или замена одних категорий другими.

Проанализировав вышеприведенные дефиниции, можно констатировать, что сегодня в обществе происходит подмена понятий, где в большинстве случаев термином «цифровой актив» обозначают криптовалюту. Такие тенденции можно соотнести с достаточно неоднозначным статусом криптовалюты и, как следствие, попытками минимизировать негативное отношение к данному феномену.

Как показывает практика, изменения в сфере информационных технологий и экономики происходят очень быстро, поэтому суть и природа цифровых активов, которые в настоящее время проходят стадию становления, еще не в полной мере осознаны и приняты современным сообществом. При этом необходимо учитывать перспективы использования цифровых активов, так как в будущем они могут стать общепризнанным эквивалентом стоимости и быть приравнены к законному платежному средству. В связи с вышеизложенным любая классификация и систематизация смежных понятий является несколько условной и в современных быстро меняющихся условиях, очевидно, не может считаться устоявшейся. 


\section{3. Компоненты в контексте определения понятия «цифровой актив»}

Цифровой актив является еще недостаточно изученным феноменом для экономики, поэтому проведение сущностного разграничения с другими объектами представляется крайне необходимым в условиях развития рынка информационных ресурсов и услуг на базе технологии блокчейн.

Действительно, на основании вышеизложенного можно сделать вывод, что на сегодняшний день понятие «цифровой актив» трактуется по-разному, что значительно затрудняет понимание многих процессов, связанных с использованием цифровых активов, и достаточно часто влияет на искажение и ошибочную трактовку информации, заложенной в базис существования цифровых активов. Такая терминологическая путаница создает устойчивые условия для дальнейшего укоренения противоречивости и неоднозначности не только самого понятия «цифровой актив», но и перспектив его использования. В связи с тем, что цифровые активы имеют большой потенциал для реального сектора экономики, появилась необходимость их нормативно-правового регулирования и закрепления в данной плоскости определения «цифровой актив» в экономико-правовом аспекте на основании установленных сущностно-смысловых особенностей [29].

ЦИФРОВОЙ АКТИВ - информационный ресурс, производный от права на ценность и обращающийся в распределенном реестре в виде уникального идентификатора.

В процессе исследования понятия цифрового актива были проанализированы определенные сущностно-смысловые особенности, представленные четырьмя составляющими:

1) экономической;

2) правовой;

3) информационной;

4) ценностной.

Принимая во внимание данные составляющие, в определении цифрового актива были выделены его структурные компоненты. 


\section{Экономическая составляющая в контексте}

определения понятия «цифровой актив» представлена в финансовой сфере наличием уникального идентификатора.

Компонента определения понятия «В виде уникального идентификатора» указывает на форму представления цифрового актива и свидетельствует о наличии уникального имени. Буквенно-числовой код, присваиваемый системой, в которой обращается цифровой актив, позволяет отличить конкретный цифровой актив в распределенном реестре данных и получить необходимую информацию о нем. Указанные свойства уникального идентификатора транзакции токена блокчейна позволяют физическим лицам и субъектам хозяйствования вести балансовый учет цифрового актива, что предоставляет им возможность проводить расчет основных экономических показателей деятельности, в частности: объема выпуска товара, себестоимости продукции, прибыли и рентабельности деятельности.

Свойство уникальности цифрового актива стало возможным с появлением технологии распределенного реестра, структура которого как раз и является гарантом сохранения информации и возможности верификации актива. Любые изменения, вносимые в распределенный реестр (блокчейн), автоматически приводят к генерированию нового уникального идентификатора, который исключает возможность дублирования и неправомерного использования актива. Информация о цифровом активе содержит следующие признаки: место его нахождения, регистрации, законодательные ограничения и другие характерные признаки и свойства. Блокчейн обеспечивает условия идентификации цифрового актива в результате присвоения ему уникального хеш-кода, позволяет закрепить такой актив за определенным субъектом.

\section{Правовая составляющая в контексте определения} понятия «цифровой актив» представлена в юридической сфере производной от права.

Проанализировав различные значения понятия «производный», можно сделать общий вывод: все определения соотносятся наличием определенного базового явления, 
предмета (производящего), что и обусловливает происхождение производного. Другими словами, «производный» возникает в результате трансформации производящего (базового явления) и к тому же может сохранять базовые свойства или опираться на них. Со своей стороны, свойства производных обусловлены свойствами производящих.

В определении понятия «цифровой актив» используется именно субъективный подход к трактованию права как вида и меры возможного поведения лица, которые регламентируются правовыми нормами.

По результатам анализа дефиниций компоненты «Производный от права» можно утверждать, что они наиболее полно отражают суть положенного в определение понятия «цифровой актив» принципа. Цифровой актив не является правом на ценность в его толковании, однако он обладает свойствами производного от права на ценность.

\section{Информационная составляющая В контексте определения понятия «цифровой актив» в сфере} информационных технологий представлена информационным ресурсом, обращающимся в распределенном реестре.

Информационный ресурс - это структурированная и организованная определенным образом информация, зафиксированная на материальном носителе, которую можно хранить, передавать, использовать, пополнять. Информационный ресурс имеет свойства практической значимости и полезности, а характеризуется возможностью многократного использования («неисчерпаемостью»). В отличие от других видов ресурсов (природные, экономические, временные) количество и качество информационных ресурсов возрастает по мере их использования. Такой кумулятивный эффект наряду с развитием современных технологий способствует стремительному приумножению информационного потенциала общества в целом.

Итак, цифровой актив является информационным ресурсом в том смысле, что представленная в цифровом виде информация о ценности имеет следующие основные свойства информационного ресурса: 
a) информация структурирована по определенным параметрам и категориям;

б) информация фиксируется на цифровом носителе;

в) информацию можно хранить, передавать, обменивать, использовать и др.

Кроме того, цифровой актив имеет дополнительное свойство - информация о ценности формируется владельцем этой ценности. Стоит отметить, что информационный ресурс в контексте определения понятия «цифровой актив» теряет такую характеристику, как возможность быть скопированным неограниченное количество раз. Это обусловлено тем, что в распределенном реестре каждый такой ресурс выражен в виде уникального идентификатора, благодаря чему обеспечиваются устойчивые условия гарантированного соответствия цифрового актива определенному субъекту. Отсюда следует важный вывод: ценность цифрового актива состоит в его уникальности и достоверности, что обеспечивается благодаря обращению цифрового актива в распределенном реестре. Основываясь на этих характеристиках, можно обозначить также высокую практическую значимость цифрового актива в экономикоправовом аспекте.

Одно из характерных свойств цифрового актива возможность обращаться в цифровой среде, а не копироваться при передаче с одного электронного адреса (хранилища, кошелька, ячейки) в другой. Объект, который обращается (цифровой актив), обязательно должен иметь не только свою среду обращения, но и четко определенные правила и условия своего нахождения в такой среде. Для возможности установления и контроля выполнения таких правил и условий нужна надежная цифровая экосистема, с возможностью масштабирования и децентрализованная, которая позволит всем участникам быть уверенными в том, что уникальность информационных ресурсов будет сохранена. Именно поэтому компонента «Распределенный реестр» занимает важное место в определении понятия цифрового актива.

Распределенная система хранения данных таких реестров является одной из самых технологически продвинутых. Она 
обеспечивает максимально возможный уровень доверия к информации благодаря обязательной процедуре ее проверки на достоверность всеми узлами распределенной среды с помощью определенного способа обеспечения консенсуса. Таким образом решается также и проблема «двойного расходования». Информацию, содержащуюся в таком реестре, невозможно удалить или модифицировать, а надежность и механизм этого метода хранения позволяет создавать в реестре записи о праве на ценности (активы). Это необходимая процедура в процессе создания цифрового актива, который, со своей стороны, требует фиксации в реестре информации о проведении оценки (аудита) и других данных владельца ценности, которая оцифровывается, в том числе и его права собственности на ценность. Для понимания сути цифрового актива важно учитывать обязательные условия: возможность подтверждения принадлежности цифрового актива определенному субъекту, а также отсутствие каких-либо способов создания копии того же цифрового актива, в частности, из-за дублирования его уникального идентификатора. Обеспечить такие условия может только технология распределенного реестра, что позволяет гарантировать уникальность идентификаторов цифровых активов и фиксировать конкретные идентификаторы за конкретными объектами.

Итак, можно сделать вывод, что возможность обращения в распределенном реестре для цифрового актива является одной из определяющих, поэтому распределенный реестр как система хранения информации - единственно возможная среда существования и обращения цифровых активов, которые, по сути, являются цифровым выражением комплекса прав и обязательств владельца реального актива в пространстве распределенного реестра.

\section{Ценностная составляющая в контексте определения} понятия «цифровой актив» представлена в сфере материальных и нематериальных благ компонентой «Ценность».

Ценность - это значение стоимости, важности, полезности чего-либо, что может выражаться различными единицами измерения в зависимости от сферы практического применения 
такой ценности и экосистемы, в которой такая ценность существует.

В определении понятия «цифровой актив» используется формулировка «производный от права на ценность», поскольку, по сути, цифровой актив является своего рода гарантированным правом претендовать на определенное значение стоимости (на ценность), заложенную в этом цифровом активе. Иными словами, цифровой актив является цифровым отображением ценности. Итак, в определении понятия цифрового актива используется именно компонента «Ценность», поскольку она широко и всеобъемлюще выражает заложенный в него смысл.

С полным текстом научно-исследовательской работы «Обоснование понятия «цифровой актив»: экономико-правовой аспект» можно ознакомиться: Kud A. A. Substantiation of the Term "Digital Asset": Economic and Legal Aspects. International Journal of Education and Science. 2019. Vol. 2. No.1. P. 41-52. doi: 10.26697/ijes.2019.1.06. http://culturehealth.org/ijes_archive/IJES, Vol.2,No1,2019_(6).pdf.

После теоретического обоснования понятия «цифровой актив» для практики крайне важным является определение критериев и показателей характеристик токена блокчейна как цифрового актива. 


\section{4. Характеристики критериев и показателей токена блокчейна как цифрового актива}

В научной литературе и в статьях информационноаналитического характера можно найти большое количество публикаций, в которых освещаются преимущества того или иного вида криптовалюты на основе определенных характеристик. Эти публикации достаточно отличаются по целям и содержанию, но их объединяет одно: зачастую такие публикации посвящены рассмотрению и популяризации какойлибо конкретной криптовалюты. При этом критерии и показатели, которые должны лежать в основе комплексных характеристик токена блокчейна, не приводятся.

Нами были проанализированы многочисленные научные публикации, на основании чего был сделан следующий вывод: основная проблема в теоретической и практической плоскости заключается в том, что индустрия информационных технологий и экономики быстро развивается, в связи с чем предлагаемые критерии определения характеристик токена блокчейна должны быть унифицированы и обоснованы в соответствии с существующими международными экономико-правовыми нормами.

Очевидно, что при отсутствии критериев (комплекса или системы критериев) невозможно дать оценку объекта, выяснить проблемы, определить степень его совершенства, спрогнозировать дальнейшее развитие и тому подобное.

Принимая это во внимание, для определения критериев токена блокчейна как цифрового актива необходимо установить наиболее существенные признаки, которые позволят охарактеризовать показатели для выяснения соответствия определенного объекта цифровому активу.

Проведенные нами исследования позволили определить критерии для оптимальной характеристики токена блокчейна как цифрового актива. В основу оптимальности положено типологию критериев: глобальный - локальный; внешний - внутренний; максимизирующий результат - минимизирующие затраты. 
Многокритериальный анализ вышеупомянутого комплекса дефиниций и оптимальности по выбору критериев позволил решить задачу определения критериев и показателей характеристики токена блокчейна в качестве цифрового актива.

В основе методики диагностики токена блокчейна на соответствие цифровому активу лежит принцип равнозначности категорий.

Использование токена блокчейна детерминировано необходимостью соблюдения условия обязательного соответствия его характеристик фундаментальным и исчерпывающим в экономико-правовом аспекте для цифрового актива категориям, соответствующим компонентам, из которых состоит определение цифрового актива.

Стоит отметить, что согласно принципу равнозначности категорий, все они равны между собой по значимости для объективного определения соответствия токена блокчейна цифровому активу. Это значит, что если токен блокчейна не соответствует минимум одной из категорий, то такой токен блокчейна не может считаться цифровым активом.

К данным категориям относятся следующие:

1. Определение цифрового актива как информационного pecypca;

2. Определение характера цифрового актива как производного от права на ценность;

3. Обращение цифрового актива в распределенном реестре;

4. Обращение цифрового актива в виде уникального идентификатора.

Реализация принципа равнозначности категорий происходит путем:

1) определения перечня критериев, которые являются достаточными для диагностики токена блокчейна на соответствие цифровому активу;

2) достаточности критериев, обусловленной дифференциацией 9 критериев цифрового актива на четыре категории в зависимости от соотношения критериев с категориями цифрового актива: 
- 1 категория: критерии № $1 ; 2 ; 3 ; 4$;

- 2 категория: критерии № 5; 6;

- 3 категория: критерии № 7; 8;

- 4 категория: критерий № 9;

3) каждому из критериев соответствует два вопроса, ответы на которые позволяют определить наличие у токена блокчейна показателя, который в свою очередь позволяет определить соответствие определенных характеристик токена блокчейна этому критерию;

4) присвоение каждой из категорий критериев равной значимости.

Таким образом, степень соответствия характеристик токена блокчейна каждой из категорий является необходимым условием для определения степени соответствия токена блокчейна цифровому активу.

Рассмотрим критерии детально.

1. Уникальность. Этот критерий указывает на неповторимость токена блокчейна и характеризуется следующим показателем: наличие документа, который фиксирует дату выпуска токена блокчейна и определяет количество токена блокчейна.

2. Идентифицируемость. Этот критерий указывает на создателя документа и характеризуется следующими показателями: наличие в документе указания на создателя токена блокчейна; возможность подтвердить правомочность создателя токена блокчейна по отношению к ценности.

3. Регламентируемость. Этот критерий указывает на урегулированность процесса реализации правомочностей в отношении токена блокчейна и характеризуется следующим показателем: наличие документа, который определяет правила и условия использования токена блокчейна.

4. Сессионность. Этот критерий определяется периодом, в течение которого существует токен блокчейна, и характеризуется следующим показателем: наличие документа, который устанавливает период обращения токена блокчейна, в том числе определяет событие, влияющее на срок действия токена блокчейна. 
5. Производность. Этот критерий указывает на происходящий от права на ценность характер токена блокчейна и раскрывается через следующий показатель: предоставляет ли токен блокчейна его владельцу доступ к комплексу прав и обязанностей владельца ценности; предоставляет ли токен блокчейна его владельцу право требовать от владельца ценности реализации комплекса прав и исполнения обязанностей.

6. Верифицируемость. Этот критерий указывает на наличие достоверных доказательств права собственности владельца на ценность и характеризуется следующими показателями: наличие документа, в котором содержится информация, достоверно указывающая на право собственности владельца на ценность, от которой происходит токен блокчейна; наличие документа, в котором содержится достоверная информация об объеме прав владельца ценности и третьих лиц на ценность, от которой происходит токен блокчейна.

7. Tранспарентность. Этот критерий указывает на возможность анализа истории операций с токеном блокчейна на основе существующих способов организации учета и характеризуется следующими показателями: отображается ли в истории операций с токеном блокчейна информация о сторонах транзакции; осуществление учета транзакций на основе предыдущих транзакций (UTXO) или на основе балансового учета токена блокчейна.

8. Децентрализованность. Этот критерий указывает на независимость от централизованных принятий решений среды, в которой обращается токен блокчейна, и характеризуется следующими показателями: наличие задокументированных механизмов управления и развития среды обращения токена блокчейна сообществом; поддержание инфраструктуры среды обращения токена блокчейна сообществом.

9. Учитываемость. Этот критерий указывает на фиксацию передачи определенного количества токенов блокчейна от одной идентифицированной стороны к другой и характеризуется следующими показателями: возможность учета передачи количества токенов блокчейна между идентифицированными сторонами в рамках транзакции; 
возможность фиксации действий сторон посредством идентификатора транзакции.

Необходимо заметить, что на сегодняшний день приведенное количество критериев является оптимальным и достаточным для получения достоверных показателей определения характеристик токена блокчейна в качестве цифрового актива с целью соответствия существующим международным правовым нормам. 


\section{РАЗДЕЛ 2 \\ ОРГАНИЗАЦИЯ И ПРОВЕДЕНИЕ ИССЛЕДОВАНИЯ ХАРАКТЕРИСТИК ТОКЕНА БЛОКЧЕЙНА}

\section{1. Исследование характеристик токена блокчейна}

Изучение токена блокчейна можно осуществлять с помощью различных методов: от простого наблюдения за его меновой стоимостью до сложных математических расчетов и построения теоретических моделей.

Исследование характеристик любого токена блокчейна предполагает использование специально разработанного нами опросника, который не требует наличия глубоких специальных знаний в области информационной и/или цифровой экономики, опрос может проводиться как индивидуально, так и коллективно. Для проведения исследования респонденту необходимо заполнить специальную форму с перечнем вопросов. По окончании исследования, то есть при заполнении всех необходимых полей, респондент получает возможность проанализировать полученные результаты, пользуясь таблицей 2.

Опросник разработан в соответствии с определенными критериями и показателями токена блокчейна, он содержит 18 вопросов, ответы на которые позволяют конкретизировать характеристики токена блокчейна. Респондент должен выбрать только один из трех вариантов ответа (А, Б, В), которые оцениваются по шкале, приведенной в таблице 2.

Информация, полученная по этой методике, позволяет определить степень соответствия токена блокчейна цифровому активу и, кроме того, охарактеризовать токен блокчейна как:

- уникальный/неуникальный;

- идентифицируемый/неидентифицируемый;

- регламентируемый/нерегламентируемый;

- сессионный/несессионный;

- производный/непроизводный;

- верифицируемый/неверифицируемый;

- транспарентный/нетранспарентный;

- децентрализованный/недецентрализованный;

- учитываемый/неучитываемый. 
Для получения максимально точных результатов вопросы упорядочены таким образом, что они уточняют каждый критерий дважды. Анализ соотношения ответов по каждому из критериев позволяет получить информацию о случайности ответов и/или ошибок.

\section{ОПРОСНИК}

Инструкция: «У Вас есть возможность провести диагностику токена блокчейна (далее - ТБ), для чего Вам необходимо ответить на 18 вопросов, которые его характеризуют. В специальной форме заполните информацию о себе и ответьте на каждый вопрос, выбрав один из предложенных вариантов: А - Да; Б - Не знаю; В - Нет.

Выбранный вариант ответа указывайте напротив каждого вопроса в специально отведенной для этого колонке. Время на ответы не ограничено».

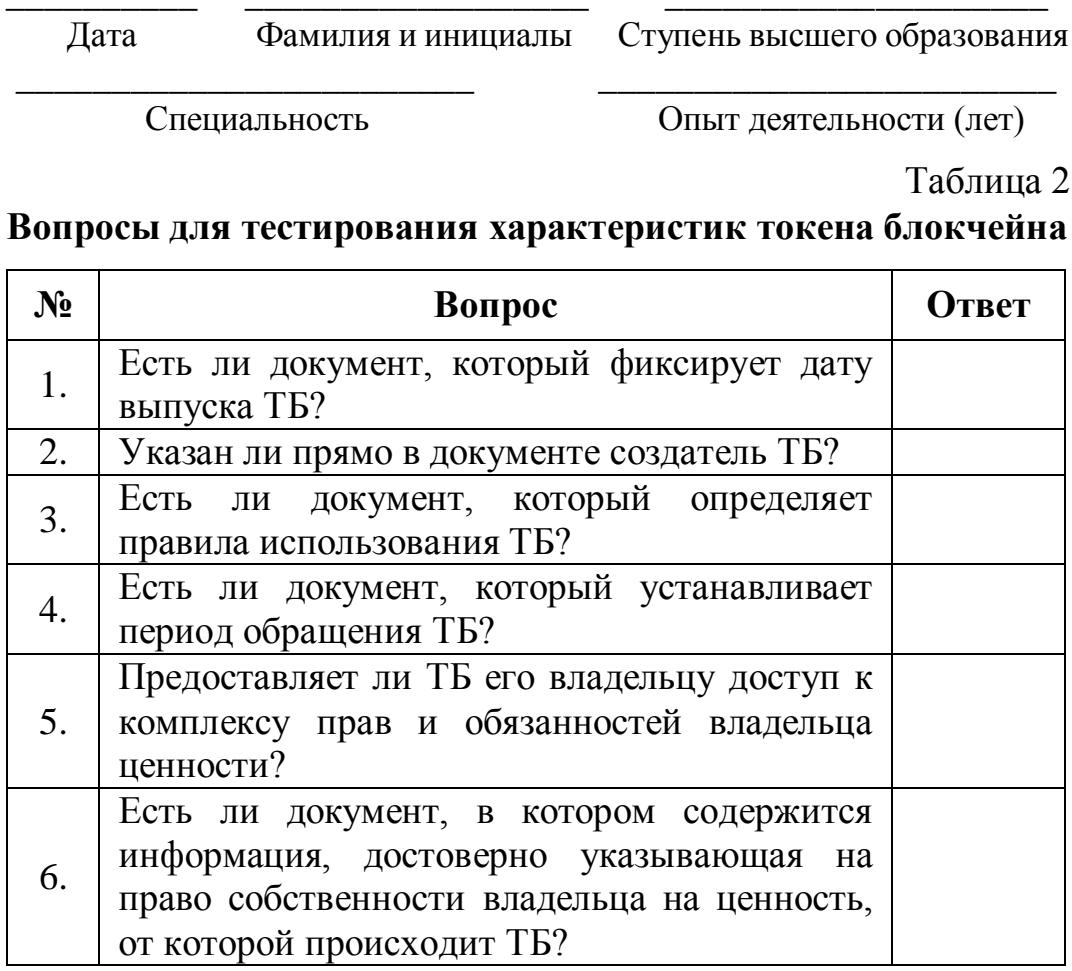




\begin{tabular}{|c|c|c|}
\hline № & Вопрос & Ответ \\
\hline 7. & $\begin{array}{l}\text { Отображается ли в истории операций с ТБ } \\
\text { информация о сторонах, принимающих } \\
\text { участие в транзакции? }\end{array}$ & \\
\hline 8. & $\begin{array}{l}\text { Существуют ли задокументированные } \\
\text { механизмы управления и развития среды } \\
\text { обращения ТБ сообществом? }\end{array}$ & \\
\hline 9. & $\begin{array}{l}\text { Возможен ли учет передачи количества ТБ } \\
\text { между идентифицированными сторонами в } \\
\text { рамках транзакции? }\end{array}$ & \\
\hline 10. & $\begin{array}{l}\text { Есть ли документ, который определяет } \\
\text { количество ТБ? }\end{array}$ & \\
\hline 11. & $\begin{array}{l}\text { Позволяет ли документ } \quad \text { подтвердить } \\
\text { правомочность создателя ТБ по отношению к } \\
\text { ценности? }\end{array}$ & \\
\hline 12. & $\begin{array}{l}\text { Есть ли документ, который определяет } \\
\text { условия использования ТБ? }\end{array}$ & \\
\hline 13. & $\begin{array}{l}\text { Есть ли документ, который определяет } \\
\text { событие, влияющее на срок действия ТБ? }\end{array}$ & \\
\hline 14. & $\begin{array}{l}\text { Предоставляет ли ТБ его владельцу право } \\
\text { требовать от владельца ценности реализации } \\
\text { комплекса прав и исполнения обязанностей? }\end{array}$ & \\
\hline 15. & $\begin{array}{l}\text { Есть ли документ, в котором содержится } \\
\text { достоверная информация об объеме прав } \\
\text { владельца ценности и третьих лиц на } \\
\text { ценность, от которой происходит ТБ? }\end{array}$ & \\
\hline 16. & $\begin{array}{l}\text { Производится ли учет транзакций на основе } \\
\text { предыдущих транзакций (UTXO) или на } \\
\text { основе балансового учета ТБ? }\end{array}$ & \\
\hline 17. & $\begin{array}{l}\text { Поддерживается ли инфраструктура среды } \\
\text { обращения ТБ сообществом? }\end{array}$ & \\
\hline 18. & 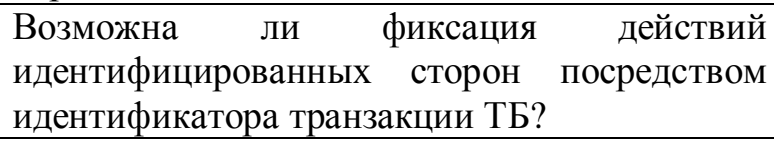 & \\
\hline
\end{tabular}




\section{2. Анализ результатов исследования}

Результаты опроса оцениваются по таблице 3 .

Максимальное суммарное количество баллов составляет 16 баллов, минимальное: 0 баллов.

В основе предоставленной таблицы лежит один из аспектов принципа равнозначности категорий, который заключается в том, что каждому из критериев соответствует два схожих по своей сути вопроса.

Таблица 3

Формирование результатов прохождения тестирования

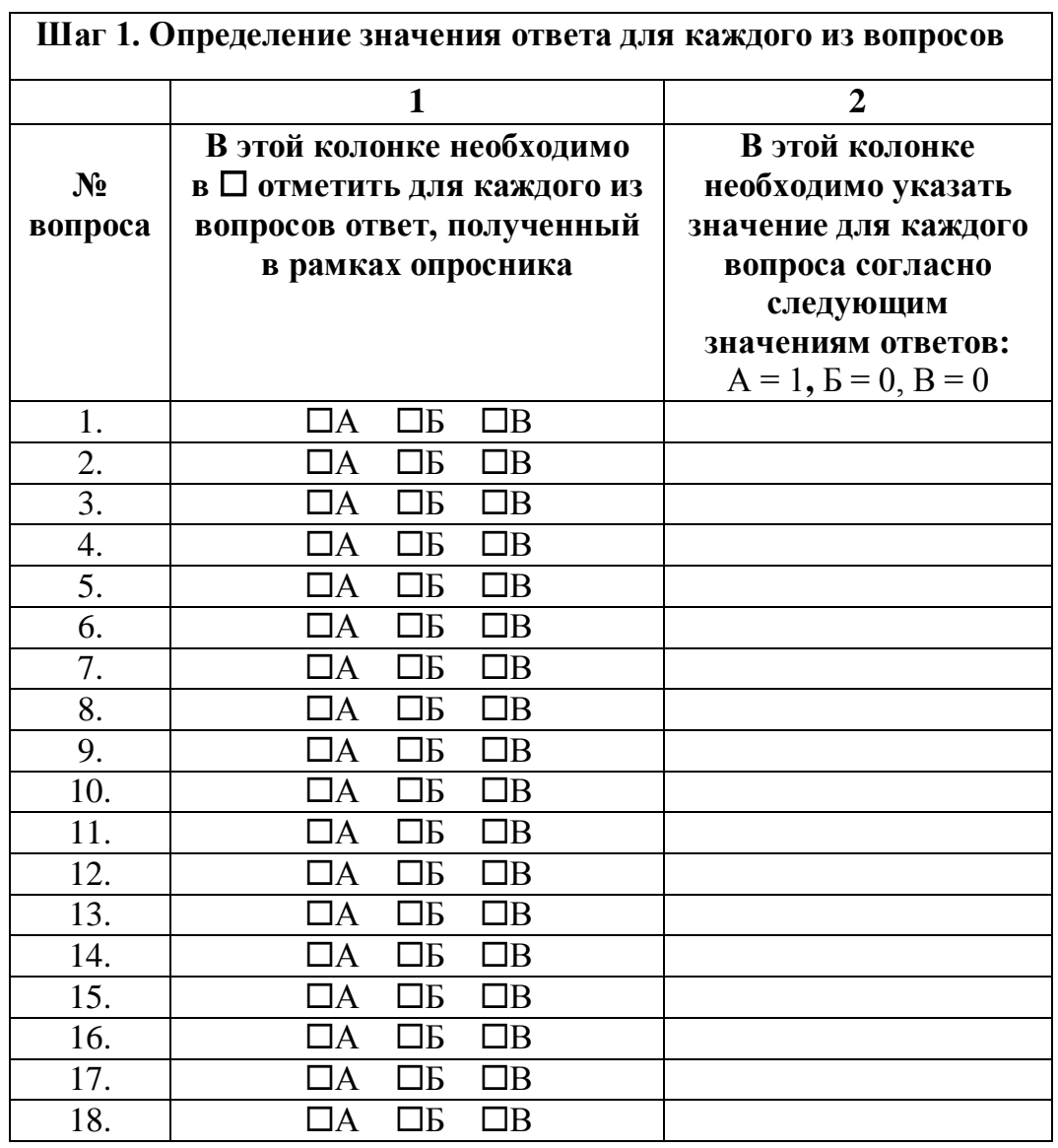




\begin{tabular}{|c|c|c|c|c|}
\hline \multicolumn{5}{|c|}{ Шаг 2. Определение значений } \\
\hline \multirow[b]{2}{*}{$\begin{array}{c}\text { № } \\
\text { кри- } \\
\text { терия }\end{array}$} & 1 & 2 & 3 & 4 \\
\hline & $\begin{array}{l}\text { Название } \\
\text { критерия }\end{array}$ & $\begin{array}{c}\text { Номера } \\
\text { двух } \\
\text { вопросов, } \\
\text { соответ- } \\
\text { ствующих } \\
\text { каждому } \\
\text { критерию }\end{array}$ & $\begin{array}{c}\text { Перенесите } \\
\text { в ячейку, } \\
\text { соответств } \\
\text { ующую } \\
\text { каждому } \\
\text { вопросу, } \\
\text { значения } \\
\text { из колонки } \\
2 \text { Шага } 1\end{array}$ & $\begin{array}{c}\text { В этой колонке } \\
\text { необходимо } \\
\text { указать значение, } \\
\text { полученное } \\
\text { путем простого } \\
\text { умножения двух } \\
\text { значений } \\
\text { ответов, } \\
\text { соответствующих } \\
\text { каждому } \\
\text { критерию, в } \\
\text { колонке } 3 \text { Шага } 2 \\
\end{array}$ \\
\hline \multirow{2}{*}{1.} & Уникаль- & 1 & & \\
\hline & ность & 10 & & \\
\hline \multirow{2}{*}{2.} & Идентифи- & 2 & & \\
\hline & цируемость & 11 & & \\
\hline \multirow{2}{*}{3.} & Регламенти- & 3 & & \\
\hline & руемость & 12 & & \\
\hline \multirow{2}{*}{4.} & Сессион- & 4 & & \\
\hline & ность & 13 & & \\
\hline \multirow{2}{*}{5.} & Производ- & 5 & & \\
\hline & ность & 14 & & \\
\hline \multirow{2}{*}{6.} & Верифици- & 6 & & \\
\hline & руемость & 15 & & \\
\hline \multirow{2}{*}{7.} & Транспа- & 7 & & \\
\hline & рентность & 16 & & \\
\hline \multirow{2}{*}{8.} & Децентрали- & 8 & & \\
\hline & зованность & 17 & & \\
\hline \multirow{2}{*}{9.} & Учитывае- & 9 & & \\
\hline & мость & 18 & & \\
\hline
\end{tabular}




\begin{tabular}{|c|c|c|c|}
\hline \multicolumn{4}{|c|}{$\begin{array}{l}\text { Шаг 3. Определение соответствия результатов, полученных в } \\
\text { рамках опросника, критериям цифрового актива }\end{array}$} \\
\hline & 1 & 2 & 3 \\
\hline № & $\begin{array}{l}\text { В эту колонку } \\
\text { перенесите } \\
\text { значения из } \\
\text { колонки } 4 \\
\text { Шага } 2\end{array}$ & Действие & $\begin{array}{c}\text { В этой колонке запишите } \\
\text { результат произведенного } \\
\text { простого умножения } \\
\text { значений, указанных в } \\
\text { колонках } 1 \text { и } 2 \\
\text { Шага } 3\end{array}$ \\
\hline 1. & & $\times 1$ & \\
\hline 2. & & $\times 1$ & \\
\hline 3. & & $\times 1$ & \\
\hline 4. & & $\times 1$ & \\
\hline 5. & & $\times 2$ & \\
\hline 6. & & $\times 2$ & \\
\hline 7. & & $\times 2$ & \\
\hline 8. & & $\times 2$ & \\
\hline 9. & & $\times 4$ & \\
\hline
\end{tabular}

Теперь Вам необходимо произвести простое сложение значений в колонке 3 Шага 3 , и полученный результат и будет составлять общую сумму баллов, которую Вы можете применить для интерпретации результатов исследования согласно таблице 4.

Общая сумма баллов: 


\section{3. Интерпретация результатов исследования}

Определение характеристик токена блокчейна на соответствие цифровому активу осуществляется на основе нормального распределения показателей, представленных в таблице 4.

Таблица 4

\section{Шкала оценки показателей токена блокчейна}

\begin{tabular}{|c|l|}
\hline $\begin{array}{c}\text { Диапазон, } \\
\text { баллы }\end{array}$ & \multicolumn{1}{|c|}{ Результат } \\
\hline $\mathbf{1 - 8}$ & $\begin{array}{l}\text { ТБ не соответствует цифровому активу, то есть не } \\
\text { является цифровым активом. } \\
\text { Полученный результат свидетельствует о достоверном } \\
\text { факте отсутствия необходимой степени соответствия } \\
\text { токена блокчейна цифровому активу }\end{array}$ \\
\hline $\mathbf{9 - 1 2}$ & $\begin{array}{l}\text { ТБ условно может быть цифровым активом, но } \\
\text { фактически им не является. } \\
\text { Такой условно-отрицательный результат основан на том, } \\
\text { что характеристики токена блокчейна могут } \\
\text { соответствовать всем четырем категориям цифрового } \\
\text { актива, но полученное при этом количество баллов не } \\
\text { является достаточным для получения достоверных } \\
\text { показателей с целью определения тБ как цифрового } \\
\text { актива }\end{array}$ \\
\hline $\mathbf{1 3 - 1 6}$ & $\begin{array}{l}\text { ТБ соответствует цифровому активу, то есть } \\
\text { является цифровым активом. } \\
\text { Данный результат указывает на необходимую степень } \\
\text { соответствия токена блокчейна цифровому активу, то } \\
\text { есть на то, что он является цифровым активом }\end{array}$ \\
\hline
\end{tabular}




\section{РАЗДЕЛ 3 \\ МАТЕМАТИЧЕСКАЯ ФОРМАЛИЗАЦИЯ МЕТОДИКИ ДИАГНОСТИКИ ХАРАКТЕРИСТИК \\ ТОКЕНА БЛОКЧЕЙНА НА СООТВЕТСТВИЕ ЦИФРОВОМУ АКТИВУ}

\section{1. Тройственная классификация по результатам диагностики токена блокчейна на соответствие цифровому активу}

В опроснике данной методики предлагается 18 вопросов, пронумерованных от 1 до 18, которые мы будем обозначать b(1), $b(2), \ldots, b(18)$. На каждый вопрос возможен один из трех ответов: «Да», «Нет», «Не знаю». Ответ на і-й вопрос формирует числовое значение а(i)

$$
\begin{aligned}
& \mathrm{a}(\mathrm{i})=\{1, \text { если ответ на } \mathrm{i} \text {-й вопрос «Да»; } \\
& 0 \text {, если ответ на i-й вопрос «Нет»; } \\
& 0 \text {, если ответ на i-й вопрос «Не знаю», } \\
& \mathrm{i}=1,2, \ldots, 18 \text {. }
\end{aligned}
$$

В зависимости от ответов на данные вопросы формируется сумма $\mathrm{C}$, состоящая из 9 слагаемых

$$
\mathrm{C}=\mathrm{X}(1)+\mathrm{X}(2)+\ldots+\mathrm{X}(9)
$$

следующим образом:

$$
\begin{aligned}
& \mathrm{X}(1)=\mathrm{a}(1) \mathrm{a}(10), \\
& \mathrm{X}(2)=\mathrm{a}(2) \mathrm{a}(11), \\
& \mathrm{X}(3)=\mathrm{a}(3) \mathrm{a}(12), \\
& \mathrm{X}(4)=\mathrm{a}(4) \mathrm{a}(13), \\
& \mathrm{X}(5)=2 \mathrm{a}(5) \mathrm{a}(14), \\
& \mathrm{X}(6)=2 \mathrm{a}(6) \mathrm{a}(15), \\
& \mathrm{X}(7)=2 \mathrm{a}(7) \mathrm{a}(16), \\
& \mathrm{X}(8)=2 \mathrm{a}(8) \mathrm{a}(17), \\
& X(9)=4 \mathrm{a}(9) \mathrm{a}(18)
\end{aligned}
$$

По результатам тестирования токен блокчейна может быть отнесен к одному из трех классов. 


\section{Класс 1}

Токен блокчейна не соответствует цифровому активу, то есть не является цифровым активом, если сформированная в результате ответов сумма С составила число меньше или равное 8

$$
\text { ТБ = НЦА, если } \mathrm{C} \leq 8 .
$$

Класс 2

Токен блокчейна условно может быть цифровым активом, но фактически им не является, если сформированная в результате ответов сумма С составила число от 9 до 12

$$
\text { ТБ = НЦА, если } 9 \leq \mathrm{C} \leq 12 .
$$

В этом случае предполагается, что токен блокчейна потенциально может стать цифровым активом, то есть соответствует границе цифрового актива, но фактически на момент тестирования им не является.

\section{Класс 3}

Токен блокчейна соответствует цифровому активу, то есть является цифровым активом, если сформированная в результате ответов сумма С составила число больше или равное 13

ТБ $\in$ ЦА, если $\mathrm{C} \geq 13$.

В результате такой тройственной классификации возникает понимание имеющей положительную (длина отрезка [9; 12] равна $3>0$ ) меру Жордана границы цифровых активов. 
3.2. Достоверность методики диагностики токена блокчейна в зависимости от величины набранных баллов

Если число набранных баллов по ответам на 18 вопросов составляет величину с, то необходимо найти вероятность

$$
\Delta=\mathrm{P}(\mathrm{C} \geq \mathrm{c})
$$

того, что $\{\mathrm{C} \geq \mathrm{c}\}$ набранная сумма составит величину не меньшую, чем с, при случайным образом выбранных ответах $\{$ «а», «Нет», «Не знаю»\} на каждый из 18 вопросов. Затем определяем достоверность Р полученного результата методики диагностики по формуле

$$
\mathrm{P}=1-\delta=1-\mathrm{P}(\mathrm{C} \geq \mathrm{c}) .
$$

Вероятностная структура полученной суммы С при случайным образом выбранных ответах на вопросы

Для определения искомой вероятности изучим вероятностную структуру суммы C

в которой

$$
\mathrm{C}=\mathrm{X}(1)+\mathrm{X}(2)+\ldots+\mathrm{X}(9)
$$

$$
\begin{aligned}
& \mathrm{X}(1)=\mathrm{a}(1) \mathrm{a}(10), \\
& \mathrm{X}(2)=\mathrm{a}(2) \mathrm{a}(11), \\
& \mathrm{X}(3)=\mathrm{a}(3) \mathrm{a}(12), \\
& \mathrm{X}(4)=\mathrm{a}(4) \mathrm{a}(13), \\
& \mathrm{X}(5)=2 \mathrm{a}(5) \mathrm{a}(14), \\
& \mathrm{X}(6)=2 \mathrm{a}(6) \mathrm{a}(15), \\
& \mathrm{X}(7)=2 \mathrm{a}(7) \mathrm{a}(16), \\
& \mathrm{X}(8)=2 \mathrm{a}(8) \mathrm{a}(17), \\
& \mathrm{X}(9)=4 \mathrm{a}(9) \mathrm{a}(18),
\end{aligned}
$$

в предположении, что $\mathrm{a}(1), \mathrm{a}(2), \ldots, \mathrm{a}(18)$ образуют набор независимых и одинаково распределенных случайных величин с распределением случайной величины а, принимающей всего два значения: 1 с вероятностью $1 / 3$,

и 0 с вероятностью $2 / 3$,

$$
\mathrm{P}(\mathrm{a}=1)=1 / 3,
$$

$$
\mathrm{P}(\mathrm{a}=0)=2 / \text {. }
$$


Фактически - это распределение есть распределение Бернулли для числа успехов в одном испытании с вероятностью успеха равной 1/3 (в случае ответа «Да» на вопрос).

В этом предположении случайные величины $\{\mathrm{X}(\mathrm{k}), \mathrm{k}=1,2$, ..., 9$\}$ независимы в совокупности и первые четыре из них, то есть $\mathrm{X}(1), \mathrm{X}(2), \mathrm{X}(3), \mathrm{X}(4)$, имеют одинаковое распределение Бернулли как случайная величина $\mathrm{X}: \mathrm{p}=\mathrm{P}(\mathrm{X}=1)=1 / 9$ и $\mathrm{q}=\mathrm{P}(\mathrm{X}$ $=0)=1-\mathrm{p}=89$. Действительно в наших предположениях, для любых $\mathrm{i} \neq \mathrm{j}$ (можно считать, $1 \leq \mathrm{i}<\mathrm{j} \leq 18$ ) произведение величин a(i) и $\mathrm{a}(\mathrm{j})$, каждая из которых равна либо 0 , либо 1 , также принимает всего два значения - 0 или 1 и

$$
\begin{aligned}
& \mathrm{P}[\mathrm{a}(\mathrm{i}) \mathrm{a}(\mathrm{j})=1]=\mathrm{P}[\mathrm{a}(\mathrm{i})=1] \mathrm{P}[\mathrm{a}(\mathrm{j})=1]=(1 / 3)(1 / 3)=1 / 9, \\
& \mathrm{P}[\mathrm{a}(\mathrm{i}) \mathrm{a}(\mathrm{j})=0]=1-\mathrm{P}[\mathrm{a}(\mathrm{i}) \mathrm{a}(\mathrm{j})=1]=1-1 / 9=89 .
\end{aligned}
$$

Общую сумму полученных баллов можно записать в виде суммы четырех слагаемых

$$
\mathrm{C}=\mathrm{C}(1)+\mathrm{C}(2)+\mathrm{C}(3)+\mathrm{C}(4),
$$

полученных баллов в соответствующих четырех категориях

$$
\begin{gathered}
\mathrm{C}(1)=\mathrm{X}(1)+\mathrm{X}(2)+\mathrm{X}(3)+\mathrm{X}(4) \\
\mathrm{C}(2)=\mathrm{X}(5)+\mathrm{X}(6) \\
\mathrm{C}(3)=\mathrm{X}(7)+\mathrm{X}(8) \\
\mathrm{C}(3)=\mathrm{X}(9)
\end{gathered}
$$

Для первой категории сумма полученных баллов

$$
\mathrm{C}(1)=\mathrm{X}(1)+\mathrm{X}(2)+\mathrm{X}(3)+\mathrm{X}(4)
$$

представляет собой число успехов в четырех независимых испытаниях с вероятностью 1/9 успеха (положительном ответе на два сгруппированных вопроса) в каждом отдельном испытании и имеет биномиальное распределение (формула Бернулли)

$$
\mathrm{P}[\mathrm{C}(1)=\mathrm{k}]=(\mathrm{n} ! /([\mathrm{k} !(\mathrm{n}-\mathrm{k}) !]))\left(\mathrm{p}^{\wedge} \mathrm{k}\right)\left(\mathrm{q}^{\wedge}(\mathrm{n}-\mathrm{k})\right), \mathrm{k}=0,1,2, \ldots, \mathrm{n},
$$

для числа успехов в серии из четырех $(\mathrm{n}=4)$ независимых испытаний с вероятностью $\mathrm{p}=1 / 9$ успеха в каждом отдельном испытании и вероятностью неудачи q $=89$.

Пример 1. Найдем вероятность $\mathrm{P}[\mathrm{C}(1) \geq 1]$ того, что суммарное число полученных в первой категории баллов не меньше одного. Она равна

$$
\mathrm{P}[\mathrm{C}(1) \geq 1]=1-\mathrm{P}[\mathrm{C}(1)=0]=1-\mathrm{q}^{\wedge} \mathrm{n}
$$


и после подстановки значений $\mathrm{n}=4, \mathrm{q}=89$

$$
\mathrm{P}[\mathrm{C}(1) \geq 1]=1-\mathrm{P}[\mathrm{C}(1)=0]=1-(89)^{\wedge} 4=2465 / 6561=0,3757 \ldots .
$$

Пример 2. Пусть $\mathrm{n}=4, \mathrm{p}=1 / 9$. Найдем вероятность Р[С(1) $\geq 3]$ того, что суммарное число полученных в первой категории баллов не меньше трех. Эту вероятность можно представить в виде суммы двух слагаемых, вероятности $\mathrm{P}[\mathrm{C}(1)=3]$ набора в этой категории 3 баллов и вероятности $\mathrm{P}[\mathrm{C}(1)=4]$ набора 4 баллов в первой категории. Обе эти вероятности находятся по формуле Бернулли для биномиального распределения

$$
\begin{aligned}
& \mathrm{P}[\mathrm{C}(1)=3]=4\left((1 / 9)^{\wedge} 3\right)(89), \\
& \mathrm{P}[\mathrm{C}(1)=4]=(1 / 9)^{\wedge} 4,
\end{aligned}
$$

благодаря чему и определяем искомую вероятность

$\mathrm{P}[\mathrm{C}(1) \geq 3]=\mathrm{P}[\mathrm{C}(1)=3]+\mathrm{P}[\mathrm{C}(1)=4]=4\left((1 / 9)^{\wedge} 3\right)(8 / 9)+$ $(1 / 9)^{\wedge} 4=33 / 9^{\wedge} 4=33 / 6561=0,005 \ldots$.

Для второй категории сумма набранных баллов

$$
\mathrm{C}(2)=\mathrm{X}(5)+\mathrm{X}(6)
$$

представляет собой удвоенное число успехов в двух независимых испытаниях с вероятностью $1 / 9$ успеха (положительном ответе на два сгруппированных вопроса для пятого и шестого критериев) в каждом отдельном испытании и имеет распределение случайной величины, которая принимает значения 0,2 и 4 с вероятностями

$$
\begin{aligned}
& \mathrm{P}[\mathrm{C}(2)=0]=(8 / 9)^{\wedge} 2=0,79012 \ldots, \\
& \mathrm{P}[\mathrm{C}(2)=2]=2(1 / 9)(89)=0,19753 \ldots, \\
& \mathrm{P}[\mathrm{C}(2)=4]=(1 / 9)^{\wedge} 2=0,01234 \ldots .
\end{aligned}
$$
баллов

Аналогично для третьей категории сумма набранных

$$
\mathrm{C}(3)=\mathrm{X}(7)+\mathrm{X}(8)
$$

представляет собой удвоенное число успехов в двух независимых испытаниях с вероятностью $1 / 9$ успеха (положительном ответе на два сгруппированных вопроса для седьмого и восьмого критериев) в каждом отдельном испытании и имеет распределение случайной величины, которая принимает значения 0,2 и 4 с вероятностями 


$$
\begin{aligned}
& \mathrm{P}[\mathrm{C}(3)=0]=(89)^{\wedge} 2=0,79012 \ldots, \\
& \mathrm{P}[\mathrm{C}(3)=2]=2(1 / 9)(89)=0,19753 \ldots, \\
& \mathrm{P}[\mathrm{C}(3)=4]=(1 / 9)^{\wedge} 2=0,01234 \ldots .
\end{aligned}
$$

Для четвертой категории число полученных баллов

$$
\mathrm{C}(4)=\mathrm{X}(9)=4 \mathrm{a}(9) \mathrm{a}(18)
$$

представляет собой умноженное на четыре число успехов в одном испытании с вероятностью $1 / 9$ успеха (положительном ответе на два сгруппированных вопроса для девятого критерия) в этом испытании и имеет распределение случайной величины, которая принимает значения 0 или 4 с вероятностями

$$
\begin{aligned}
& \mathrm{P}[\mathrm{C}(4)=0]=89, \\
& \mathrm{P}[\mathrm{C}(4)=4]=1 / 9 .
\end{aligned}
$$

Вероятность получить не меньше 13 баллов в сумме С

Найдем точное значение вероятности Р[C $\geq 13]$ в предположении о равновозможном выборе (случайным образом выбранных) ответов на все 18 вопросов из трех возможных ответов \{《Да», «Нет», «Не знаю»\}. Таким образом, имеем

$$
\mathrm{C}=\mathrm{C}(1)+\mathrm{C}(2)+\mathrm{C}(3)+\mathrm{C}(4)
$$

суммарное число баллов, которое складывается из полученных баллов в четырех категориях. При этом максимальное число баллов по каждой категории равно:

$$
\max [\mathrm{C}(\mathrm{k}), \mathrm{k}=1,2,3,4]=4 \text {. }
$$

Исходя из этого, максимально возможное суммарное число баллов $\mathrm{C}^{\wedge}(\max )$ в результате равно шестнадцати

$$
\mathrm{C}^{\wedge}(\max )=\max [\mathrm{C}(1)+\mathrm{C}(2)+\mathrm{C}(3)+\mathrm{C}(4)]=4+4+4+4=16 \text {. }
$$

Отсюда и из содержания целочисленных множеств принимаемых величинами значений

$$
\begin{aligned}
& \mathrm{C}(1)=\{0 ; 1 ; 2 ; 3 ; 4\}, \mathrm{C}(2)=\{0 ; 2 ; 4\}, \mathrm{C}(3)=\{0 ; 2 ; 4\}, \mathrm{C}(4) \\
= & \{0 ; 4\},
\end{aligned}
$$

13 баллов и более в сумме

$$
\mathrm{C}=\mathrm{C}(1)+\mathrm{C}(2)+\mathrm{C}(3)+\mathrm{C}(4)
$$

получается, если только $\mathrm{C}(4)=4$ (для $\mathrm{C}(4)=0$ общая сумма $\mathrm{C} \leq 16-4=12<13$ меньше тринадцати). Если же $\mathrm{C}(4)=4$, то при этом случайное событие $\{\mathrm{C} \geq 13\}$ представляется в виде суммы 
несовместных случайных событий (для суммы С не меньше 13 возможны только следующие варианты):

$$
\begin{aligned}
& \mathrm{A}=\{\mathrm{C}(4)=4, \mathrm{C}(3)=4, \mathrm{C}(2)=4, \mathrm{C}(1) \geq 1\}, \\
& \mathrm{B}=\{\mathrm{C}(4)=4, \mathrm{C}(3)=4, \mathrm{C}(2)=2, \mathrm{C}(1) \geq 3\}, \\
& \mathrm{D}=\{\mathrm{C}(4)=4, \mathrm{C}(3)=2, \mathrm{C}(2)=4, \mathrm{C}(1) \geq 3\} .
\end{aligned}
$$

Благодаря независимости случайных величин $\{\mathrm{C}(1), \mathrm{C}(2)$, $\mathrm{C}(3), \mathrm{C}(4)\}$ вероятность каждого из этих трех событий определяется как произведение вероятностей событий, относящихся к каждой из этих величин. При этом нам потребуются в качестве множителей следующие ранее найденные вероятности:

$$
\begin{aligned}
& \mathrm{P}[\mathrm{C}(4)=4]=1 / 9 \\
& \mathrm{P}[\mathrm{C}(3)=4]=(1 / 9)^{\wedge} 2=1 / 81 \\
& \mathrm{P}[\mathrm{C}(2)=4]=(1 / 9)^{\wedge} 2=1 / 81 \\
& \mathrm{P}[\mathrm{C}(1) \geq 1]=\left(\left(9^{\wedge} 4-8^{\wedge} 4\right)\right) 9^{\wedge} 4=2465 / 6561 \\
& \mathrm{P}[\mathrm{C}(2)=2]=2(1 / 9)(89)=1681 \\
& \mathrm{P}[\mathrm{C}(3)=2]=2(1 / 9)(89)=1681 \\
& \mathrm{P}[\mathrm{C}(1) \geq 3]=4\left((1 / 9)^{\wedge} 3\right)(8 / 9)+(1 / 9)^{\wedge} 4=33 / 9^{\wedge} 4=33 / 6561 .
\end{aligned}
$$

Итак,

$\mathrm{P}[\mathrm{C}(4)=4, \mathrm{C}(3)=4, \mathrm{C}(2)=4, \mathrm{C}(1) \geq 1]=\mathrm{P}[\mathrm{C}(4)=4] \mathrm{P}[\mathrm{C}(3)=$ $4] \mathrm{P}[\mathrm{C}(2)=4] \mathrm{P}[\mathrm{C}(1) \geq 1]$

После подстановки значений полученных выше вероятностей

$\mathrm{P}[\mathrm{C}(4)=4, \mathrm{C}(3)=4, \mathrm{C}(2)=4, \mathrm{C}(1) \geq 1]=$ $(1 / 9)\left((1 / 9)^{\wedge} 2\right)\left((1 / 9)^{\wedge} 2\right)\left[\left(\left(9^{\wedge} 4-8^{\wedge} 4\right)\right) 9^{\wedge} 4\right]=\left(\left(9^{\wedge} 4-8^{\wedge} 4\right)\right) 9^{\wedge} 9$,

\section{или}

$\mathrm{P}[\mathrm{C}(4)=4, \mathrm{C}(3)=4, \mathrm{C}(2)=4, \mathrm{C}(1) \geq 1]=\left(\left(9^{\wedge} 4-8^{\wedge} 4\right)\right) 9^{\wedge} 9=$ $2465 / 387420489$.

Далее

$\mathrm{P}[\mathrm{C}(4)=4, \mathrm{C}(3)=4, \mathrm{C}(2)=2, \mathrm{C}(1) \geq 3]=\mathrm{P}[\mathrm{C}(4)=4] \mathrm{P}[\mathrm{C}(3)=$ 4] $\mathrm{P}[\mathrm{C}(2)=2] \mathrm{P}[\mathrm{C}(1) \geq 3]$

После подстановки значений полученных выще вероятностей

$\mathrm{P}[\mathrm{C}(4)=4, \mathrm{C}(3)=4, \mathrm{C}(2)=2, \mathrm{C}(1) \geq 3]=$ $(1 / 9)\left((1 / 9)^{\wedge} 2\right)\left(169^{\wedge} 2\right)\left(33 / 9^{\wedge} 4\right)=5289^{\wedge} 9$,

\section{или}


$\mathrm{P}[\mathrm{C}(4)=4, \mathrm{C}(3)=4, \mathrm{C}(2)=2, \mathrm{C}(1) \geq 3]=5289^{\wedge} 9=$ 528387420489 .

И, наконец,

$\mathrm{P}[\mathrm{C}(4)=4, \mathrm{C}(3)=2, \mathrm{C}(2)=4, \mathrm{C}(1) \geq 3]=\mathrm{P}[\mathrm{C}(4)=4] \mathrm{P}[\mathrm{C}(3)=$ $2] \mathrm{P}[\mathrm{C}(2)=4] \mathrm{P}[\mathrm{C}(1) \geq 3]$

После подстановки значений полученных выше вероятностей

$\mathrm{P}[\mathrm{C}(4)=4, \mathrm{C}(3)=2, \mathrm{C}(2)=4, \mathrm{C}(1) \geq 3]=$ $(1 / 9)\left(169^{\wedge} 2\right)\left((1 / 9)^{\wedge} 2\right)\left(33 / 9^{\wedge} 4\right)=5289^{\wedge} 9$,

или

$\mathrm{P}[\mathrm{C}(4)=4, \mathrm{C}(3)=2, \mathrm{C}(2)=4, \mathrm{C}(1) \geq 3]=5289^{\wedge} 9=528 / 387420489$.

Благодаря аксиоме сложения вероятностей (третьей аксиоме теории вероятностей) искомую вероятность $\mathrm{P}[\mathrm{C} \geq 13]$ можно найти в виде суммы вероятностей трех несовместных событий

$\mathrm{P}[\mathrm{C} \geq 13]=\mathrm{P}(\mathrm{A})+\mathrm{P}(\mathrm{B})+\mathrm{P}(\mathrm{D})=2465 / 9^{\wedge} 9+5289^{\wedge} 9+5289^{\wedge} 9$ $=3521 / 387420489$,

или искомая вероятность равна

$\delta=\mathrm{P}[\mathrm{C} \geq 13]=3521 / 387420489=9,0883 \ldots / 10^{\wedge} 6<1 / 10^{\wedge} 5$

Таким образом, точная оценка достоверности результатов диагностики токена блокчейна на соответствие цифровому активу

$P=1-P[C \geq 13]=1-3521 / 387420489=$ $\underline{387416968387420489=0,9999909 \ldots>0,99999}$.

Таким образом, достоверность данной методики диагностики токена блокчейна на соответствие цифровому активу составляет больще, чем 0,99999. Это значит, что случайным образом выбранные ответы на 18 вопросов по этой методике приведут к положительному результату диагностики токена блокчейна на соответствие цифровому активу с вероятностью меньшей, чем $1 / 10^{\wedge} 5$.

На основании вышеизложенного можно говорить о фактическом математическом обосновании методики диагностики токена блокчейна на соответствие множеству цифровых активов. Эта методика позволяет с подавляющей 
(близкой к единице) вероятностью ответить на вопрос: является ли конкретный токен блокчейна цифровым активом или нет? Если полученная сумма баллов в результате ответов на 18 вопросов, подсчитанная по этой методике, больше или равна тринадцати $\mathrm{C} \geq 13$, диагностированный токен блокчейна соответствует цифровому активу, то есть является цифровым активом.

Если же полученная сумма $\mathrm{C}<13$, то токен блокчейна не соответствует цифровому активу, то есть не является цифровым активом. Но при этом в данном множестве сумм \{С $\leq 12\}$ выделяется подмножество $\{9 \leq \mathrm{C} \leq 12\}$, и если результаты тестирования характеристик токена блокчейна входят в данное подмножество, то данный токен условно может быть цифровым активом, но фактически им не является и с большей вероятностью соответствует границе цифрового актива. Это так называемое граничное множество состояний (не соответствующих цифровым активам), но благоприятствующее переходу токена блокчейна в класс 3 - во множество цифровых активов (условно-отрицательный ответ). И однозначно отрицательный ответ при полученной сумме $\mathrm{C} \leq 8$. В этом и состоит тройственная классификация (разделения на три множества целых значений) числового отображения ответов на 18 вопросов по данной методике:

$$
0 \leq \mathrm{C} \leq 8-\text { однозначно нет, не ЦА; }
$$

$9 \leq \mathrm{C} \leq 12$ - нет, но существует возможность перехода в ЦА;

$$
\mathrm{C} \geq 13 \text { - да, ЦА. }
$$




\section{ВЫВОДЫ}

Использование современных теоретических и методикоматематических основ для изучения вопроса исследования токена блокчейна с целью определения степени соответствия цифровому активу позволили сформулировать следующие выводы.

1. Анализ литературных источников позволил исследовать следующие понятия: «токен блокчейна», «цифровая валюта», «виртуальная валюта», «криптовалюта», «цифровой актив», «виртуальный актив», «криптоактив», «цифровые деньги», «виртуальные деньги», «электронные деньги» и другие. Теоретический анализ научной литературы свидетельствует, что в современной экономической науке и практике, в связи с высокой динамикой развития новых форм представления цифровых технологий и значительного отставания в формировании соответствующего теоретического основания и конкретного понятийно-категориального аппарата, суть и природа цифровых активов еще не в полной мере осознаны и приняты современным сообществом. При этом на сегодняшний день наиболее обоснованным в экономико-правовом аспекте и, как следствие, корректным является следующее определение: цифровой актив - информационный ресурс, производный от права на ценность и обращающийся в распределенном реестре в виде уникального идентификатора.

2. Определение особенностей основных понятий исследования, например, понятия «цифровой актив» и четырех структурных компонент в его определении, и развитие цифровой и информационной экономики в международном правовом поле позволили установить:

- четыре категории для объективного определения соответствия токена блокчейна цифровому активу;

- достаточность критериев, обусловленную дифференциацией 9 критериев цифрового актива на четыре категории в зависимости от соотношения критериев с категориями цифрового актива; 
- показатели характеристики токена блокчейна как цифрового актива, в частности такие: уникальность, идентифицируемость, регламентируемость, сессионность, производность, верифицируемость, транспарентность, децентрализованность, учитываемость.

3. В соответствии с определенными в исследовании критериями и показателями токена блокчейна разработана методика диагностики, опросник, которой содержит 18 вопросов, а ответы позволяют соотнести характеристики токена блокчейна с цифровым активом. Результаты опроса оцениваются исходя из принципа равнозначности категорий цифрового актива, а именно сгруппированности вопросов на основании критериев и, соответственно, позволяют определить степень соответствия токена блокчейна категориям цифрового актива.

4. Предложенная математическая формализация методики диагностики характеристик токена блокчейна на соответствие цифровому активу позволяет говорить о фактическом математическом обосновании и достоверности данной методики. 


\section{ТЕЗАУРУС}

Актив (Asset) - имущество и/или права (имущественные, неимущественные) физического лица и/или субъекта хозяйственной деятельности, представляющие ценность, в том числе цифровые активы, деньги и разного рода работы, услуги.

Балансовый учет токенов блокчейна (Balance accounting of blockchain tokens) - это метод регистрации и учета транзакций, реализуемый программным обеспечением узла сети блокчейн, позволяющий определить разницу между поступлениями и расходами единиц учета на определенный момент по адресу их учета.

Балансовый учет цифровых активов (Balance accounting of digital assets) - метод определения разницы между поступлениями и расходами цифровых активов на определенный момент по адресу их учета, который основывается на регистрации и учете транзакций токена блокчейна и реализуется программным обеспечением узла сети блокчейна.

Блокчейн (Blockchain) - вид распределенного реестра, который представляет собой выстроенную по определенным правилам последовательную цепочку, которая формируется из блоков транзакций. При этом каждый последующий блок данной структуры содержит информацию о предыдущем блоке, таким образом, в целом цепочка хранит всю историю совершенных транзакций.

Валюта (Currency) - любой товар, способный выполнять функцию денег при осуществлении обмена товарами на рынке внутри страны или на международном рынке.

Виртуальная валюта (Virtual currency) - создаваемое имущество, которое учитывается посредством применения информационно-телекоммуникационных технологий; не номинировано в валюте государств, которое может использоваться неопределенным кругом лиц для осуществления платежей, не относится к электронным денежных средствам и законным средствам платежа.

Виртуальный актив (Virtual asset) - выражение валюты в определенной среде или ситуации. В этом контексте валюту 
можно определить либо как средство обмена, либо как собственность, которая имеет ценность в определенной среде. Денежные виртуальные активы часто называют виртуальной валютой.

Виртуальные деньги (Virtual money) - внутренняя электронная валюта сетевых сообществ, сфера использования которых ограничена приобретением и продажей виртуальных товаров внутри такого сообщества.

Документ (Document) - зафиксированная в цифровом виде информация, которой устанавливаются определенные атрибуты и свойства цифрового объекта, правила и условия его создания и обращения в информационной системе, а также порядок его исполнения. Существует также в комплексном виде, то есть представляет собой совокупность структурно-самостоятельных цифровых документов, которые устанавливают отдельно взятые аспекты, которые, согласно своему целевому назначению, регламентирует документ в целом.

\section{Идентификатор транзакции токена блокчейна} (Identifier of a blockchain token transaction) - уникальный набор символов из букв и цифр определенной длины, который присваивается транзакции токена блокчейна в среде его обращения.

Имущественное право (Property law) - абсолютное субъективное гражданское право, обеспечивающее возможность его владельцу своими непосредственными действиями извлекать полезные свойства из самой индивидуально-определенной вещи (вещи как таковой) с целью удовлетворения своего собственного интереса.

Информационный ресурс (Information resource) структурированная и организованная определенным образом информация, зафиксированная на материальном носителе, которую можно хранить, передавать, использовать, пополнять; обладает свойствами практической значимости и полезности, а также возможностью многократного использования.

Криптоактив (Cryptoasset) - цифровое выражение ценности, что стало возможным благодаря достижениям в области криптографии и технологии распределенного реестра; 
криптоактивы выражены в своих собственных единицах учета и могут быть переданы в одноранговой сети без посредников.

Криптовалюта (Cryptocurrency) - цифровое выражение ценности, предназначенное для создания одноранговой альтернативы законному платежному средству, выданному правительством; используется как средство обмена общего назначения (независимо от любого центрального банка); обеспечено механизмом, известным как криптография; может быть преобразовано в законное платежное средство и наоборот.

Криптография (Cryptography) - наука о методах обеспечения конфиденциальности (невозможности прочтения информации посторонним), целостности данных (невозможности незаметного изменения информации), аутентификации (проверки подлинности авторства или других свойств объекта), а также невозможности отказа от авторства.

Мера Жордана (Jordan measure) - наиболее простой и естественный способ определения понятия длины, площади, объема множества, понимаемый как один и тот же конечный предел последовательностей верхних и нижних оценок искомой величины в процессе стремления положительной единицы измерения к нулю.

Правила и условия использования ТБ (Terms and conditions of using a ВТ) - это отображенные в информационном ресурсе сведения, которые определяют лежащие в основе закономерности, предписания и принципы руководящего характера для обращения буквенно-цифрового идентификатора, зарегистрированного в блокчейне и предоставляющего своему владельцу определенный объем прав доступа к информационному ресурсу.

Производный от права (Derivative of the right) - свойство объекта, предоставляющее его владельцу право, которое образуется от права на ценность.

Создатель ТБ (Creator of a ВТ) - субъект, который прямо или опосредовано (в качестве заказчика) выражает стоимость, важность, полезность объекта путем создания буквенноцифрового идентификатора, зарегистрированного в блокчейне и 
предоставляющего своему владельцу определенный объем прав доступа к информационному ресурсу.

Технология распределенного реестра (Distributed ledger technology) - новый подход к записи и обмену данными между несколькими хранилищами данных (также известных как книги или реестры). Эта технология позволяет записывать, совместно использовать и синхронизировать транзакции и данные в распределенной сети различных участников сети.

Токен блокчейна (Blockchain token) - это единица учета, обращающаяся в распределенном реестре посредством транзакции с уникальным идентификатором.

Финансовая система (Financial system) - форма организации денежных отношений между всеми субъектами воспроизводственного процесса по распределению и перераспределению совокупного общественного продукта.

Формула Бернулли (Bernoulli formula) - представляет вероятностное распределение для числа наступлений случайного события в конечной серии независимых испытаний в одинаковых условиях.

Хеш транзакции (Transaction hash) - число фиксированной длинны, которое ставится в соответствие данным произвольной длины таким образом, чтобы вероятность появления различных данных с одинаковым хешем приближалась к нулю, а восстановить данные по их хешу было как можно труднее.

Цифровой актив (Digital asset) - информационный ресурс, производный от права на ценность и обращающийся в распределенном реестре в виде уникального идентификатора.

Ценность (Value) - значение стоимости, важности, полезности чего-либо, которое также может выражаться различными единицами измерения в зависимости от области практического использования такой ценности и экосистемы, в которой есть такая ценность.

Электронные деньги (Electronic money) специализированный электронный импульс (файл), который записан на носитель, содержащий характеристику денег и количественное выражение стоимости денежного эквивалента, 
является предоплаченным финансовым продуктом, выпускается после получения эмитентом денежных средств на сумму не меньше стоимости денежного эквивалента, и являются обязательствами эмитента, которому корреспондируется право требования к владельцу таких электронных денег по их погашению.

UTXO (Unspent Transaction (TX) Output) - это неизрасходованный выход транзакции, который можно использовать как вход в новой транзакции. 


\section{СПИСОК ИСПОЛЬЗОВАННОЙ ЛИТЕРАТУРЫ}

1. European Central Bank. Virtual currency schemes. Frankfurt am Main: European Central Bank, 2012. 54 p. URL: https://www.ecb.europa.eu (Last accessed: 08.12.2018).

2. European Central Bank. Virtual currency schemes - a further analysis. Frankfurt am Main: European Central Bank, 2015. 38 p. URL: https://www.ecb.europa.eu (Last accessed: 08.12.2018).

3. Virtual currencies and beyond: Initial considerations/He D., etc. International Monetary Fund, 2016. 42 p. URL: https://www.imf.org (Last accessed: 11.11.2018).

4. Committee on Payments and Market Infrastructures. Digital currencies. Bank for International Settlements, 2015. 21 p. URL: https://www.bis.org (Last accessed: 19.11.2018).

5. European Banking Authority. Opinion on "virtual currencies". European Banking Authority, 2014. 46 p. URL: https://www.eba.europa.eu (Last accessed: 24.12.2018).

6. European Securities and Markets Authority. Warning on the risks of virtual currencies. URL: https://www.esma.europa.eu (Last accessed: 03.12.2018).

7. Natarajan H., Krause S. K., Gradstein H. L. Distributed ledger technology (DLT) and blockchain: Fintech Note no. 1. Washington, D.C.: World Bank Group. 2017. 60 p. URL: http://documents. worldbank.org (Last accessed: 07.12.2018).

8. Financial Action Task Force. Virtual currencies - key definitions and potential AML/CFT risks. Paris: FATF/OECD, 2014. 15 p. URL: http://www.fatf-gafi.org (Last accessed: 27.11.2018).

9. Houben R., Snyers A. Cryptocurrencies and blockchain: Legal context and implications for financial crime, money laundering and tax evasion. 2018. URL: http://www.europarl.europa.eu (Last accessed: 21.11.2018).

10. Вахрушев Д. С., Железов О. В. Криптовалюта как феномен современной информационной экономики: проблемы теоретического осмысления. Науковедение. 2014. Вып. 5(24). C. $4-15$.

11. Xaurum Official. The difference between cryptocurrency and digital assets, and why should holders care? Medium: web portal. 
Last updated: 20.03.2018. URL: https://medium.com (Last accessed: 14.12.2018).

12. What is cryptocurrency: 21st-century unicorn - or the money of the future? Blockgeeks: web portal. Last updated: 13.09.2018. URL: https://blockgeeks.com (Last accessed: 22.12.2018).

13. Агапова А. І., Сігайов А. О. Вплив криптовалют на фінансову систему в Україні. Сучасні проблеми економіки $i$ підприємництво. 2017. Вип. 20. С. 134-141.

14. Танклевська Н. С., Петренко В. С., Карнаушенко А. С. Економічна сутність та види криптовалюти у світі. Бізнеснавігатор. 2017. Вип. 4-2(43). С. 133-138.

15. Cryptocurrency vs Blockchain: What's the difference? eToroX: website. URL: https://www.etorox.com (Last accessed: 07.01.2019).

16. Introduction to cryptocurrencies. Kraken: website. URL: https://www.kraken.com (Last accessed: 15.12.2018).

17. Абрамчук М. Ю., Салтикова Г. В., Білоус Ю. Г. Криптовалюта як інформаційно-комунікаційний інструмент фінансово-економічних відносин: обліковий аспект. Гроші, фінанси і кредит. 2018. Вип. 18. С. 293-299.

18. Understanding cryptocurrency: How it works, what drives it, should you buy it? Interesting Engineering: website. URL: https://interestingengineering.com (Last accessed: 27.12.2018).

19. Воскресенская Е. В. О необходимости правового регулирования виртуальных валют. Вестник Омской юридической академии. 2018. Т. 15 . № 2. С. 148-151. doi:10.19073/2306-1340-2018-15-2-148-151

20. Braddick K., Bailey A., Ramsden D. Cryptoassets taskforce: Final report. $2018 . \quad$ URL: https://gov.uk/government/publications (Last accessed: 11.12.2018).

21. He D. Crypto assets may one day reduce demand for central bank money. Finance and Development. 2018. Vol. 55. Iss. 2. P. 1316. URL: https://www.elibrary.imf.org (Last accessed: 03.09.2018).

22. The Tech Dictionary and IT Encyclopedia. TechTarget: website. URL: https://whatis.techtarget.com (Last accessed: 15.12.2018). 
23. Про внесення змін до Податкового кодексу України щодо оподаткування операцій 3 віртуальними активами в Україні: проект Закону від 14.09.2018 № 9083 // Інформ.-правова система «Ліга-Закон»/BP України. URL: http://search.ligazakon.ua/__doc2.nsf/link1/JH70B00A.html (дата звернення: 05.11.2018).

24. What exactly is a digital asset \& How to get the most value from them? MerlinOne: website. URL: https://merlinone.com (Last accessed: 22.12.2018).

25. Windsor R. Defining Digital Assets. Digital Asset News: web portal. Last updated: 11.08.2017. URL: https://digitalassetnews.org (Last accessed: 21.12.2018).

26. Medhat M. Digital asset management and IoT - the innovation path from "digits" to "value". CIOReview: website. URL: https://www.cioreview.com (Last accessed: 10.12.2018).

27. Дюдикова Е. И. Перспективы развития электронных денег как элемента национальной платежной системы Российской Федерации: автореф. дисс. на соискание уч. степени канд. екон. наук: 08.00.10. Ставрополь. 2017. 28 с.

28. Проценко А. Т. Правове регулювання обігу електронних грошей в Україні: дис. … канд. юр. наук: 12.00.07/Міжрегіональна академія управління персоналом. Київ, 2016. $202 \mathrm{c}$.

29. Kud A. A. Substantiation of the Term "Digital Asset": Economic and Legal Aspects. International Journal of Education and Science. 2019. Vol. 2. No. 1. P. 41-52. doi:10.26697/ijes.2019.1.06

30. Kud A., Pypenko I. Social and Economic Foundation of the Implementation of Blockchain-Based Systems of Digital Assets in Developing Countries. International Journal of Education and Science: Conference Abstracts. 2018. Vol. 1. No. 3-4. P. 30. doi:10.26697/ijes.2018.3-4.30 
Методика діагностики токену блокчейну на відповідність цифровому активу

Методичний посібник

(Рос. мовою)

КУДь Александр Александрович

ISBN 978-617-7089-05-5

DOI 10.26697/9786177089055.2019

Видасться в авторській редакції

Відповідальний випусковий: І. С. Пипенко

Комп'ютерне складання та верстання: Я. Ю. Свячена

\author{
Формат 80x64\% \\ Гарн. «Тіmes». Папір мелований. Друк офсетний. \\ Ум. друк. арк. 3,3. Зам. № 1-23. \\ Тираж 5000 пр.
}

Науково-дослідний інститут ХОГОКЗ

Харківська обласна громадська організація “Культура Здоров'я"

Україна, 61105, м. Харків, пров. Забайкальський, 6/6.

http://publisher.culturehealth.org; тел./факс: (057)775-75-23.

Emails: CultureHealth@ukr.net; KOSOCH@gmail.com;

Свідоцтво про державну реєстрацію видавництва

ДК № 4387 від 10.08.2012 